\title{
Ahilik Sistemi Değerleri Yönetim ve Eğitimi
}

\section{Management and Education in Akhism System}

\author{
Ahmet ÜNSÜR, Sorumlu Yazar, Dr. (Em. Öğretim üyesi) \\ Sakarya Üniversitesi, İ̈BF Çalışma Ekonomisi ve Endüstri İlişkileri Bölümü, Türkiye. \\ aunsur37@gmail.com \\ https://orcid.org/0000-0001-6560-4620
}

\author{
ISSN: 1303-880X \\ e-ISSN: 2667-7504 \\ http://ded.dem.org.tr
}

Makale Türü / Article Type:

Derleme Makalesi / Review Article

Geliş Tarihi / Received Date: 30.12.2019

Kabul Tarihi / Accepted Date: 12.05.2020

Yayın Tarihi / Published Date: 25.06.2020

Tr/En: $\operatorname{Tr}$

Intihal / Plagiarism: Bu makale, en az iki hakem tarafindan incelendi ve intihal içermediği teyit edildi. / This article has been reviewed by at least two referees and scanned via a plagiarism software.
Atıf/Citation: Ünsür, A. (2020). Ahilik sistemi değerleri yönetim ve eğitimi. Değerler Eğitimi Dergisi, 18 (39), s.297-337. https://doi.org/10.34234/ded.667411 
Öz: Ahilik, Selçuklu ve Osmanlı devletleri döneminde değerleri ön plana çıkararak iktisadi ve sosyal hayata yön veren bir örgütlenme biçimidir. Bu yapıyı asırlarca ayakta tutan en önemli faktörün süreklilik ve kararlılıkla uygulanan değerler eğitimi olduğu anlaşılmaktadır. Ahilikte uygulanan değerler eğitimi politika, yöntem ve uygulama olarak dönemi itibarıla en ileri unsurları içermesi yanında günümüze 1şık tutacak birtakım özelliklere de sahiptir. Bunların başında ise insan yetiştirme anlayışı (erdemli birey) gelmektedir. Günümüz eğitim sistemlerinin seküler yapısı nedeniyle değerlerle bütünleşik erdemli bireyler yetiştirmede başarısız oldukları görülmektedir. İş ve sosyal hayatın değişik platformlarında yaşanan ahlaki sorunlar bu durumun bir göstergesi durumundadır. Bu tür sorunları ortadan kaldırmak amacıyla yapılan çalışmaların ise (etik kodlar oluşturma, etik dersleri vb.) palyatif çözümler olmaktan öteye gidemediği görülmektedir. Literatür taramasına dayalı derleme niteliğindeki bu çalışmanın amacı, Ahilik sistemini ayakta tutan değerleri ve bu değerlerin eğitimde nasıl kullanıldığını incelemek ve günümüz eğitim sistemi açısından değerlendirilebilecek yönlerini belirlemektir. Çalışma sonucu, Ahilik sisteminin başarısında ahlaki değerlerin eğitimin her aşamasına (örgün/yaygın-ev/iş-okul/okul dış1) yansıtılmasının (değerlerle eğitim) en önemli faktör olduğu belirlenmiştir. Günümüz eğitim sisteminde böyle bir anlayışın benimsenmesi ve kararlılıkla uygulanması halinde iktisadi ve sosyal hayatta yaşanan sorunların büyük ölçüde ortadan kalkması kuvvetle muhtemeldir.

Anahtar Kelimeler: Ahilik, Değerler, Yönetim, Eğitim, Değerler eğitimi.

$\&$

Abstract: Akhism is a form of organization that guides economic and social life by emphasizing the values of Seljuk and Ottoman eras. The most important factor that maintains this structure alive for centuries is the determination and continuity in the application of values education. Apart from the fact that most advanced elements of policy, method and practice used in values applied in Akhism some other features will also shed light on the present day. The most important of these is the conception of human development (raising righteous individual). Due to the secular nature of today's education systems, they have failed to raise virtuous individuals that internalize values. The moral problems manifested in different platforms of business and social life are an indicator of this situation. It is seen that the studies carried out to eliminate such problems (creating ethical codes, ethics lessons, etc.) do not go beyond palliative solutions. The purpose of this study, which is based on the literature review, is to 
examine how these values are used in education and to determine the aspects that can be evaluated in terms of today's education system. As a result of the study, it has been determined that the most important factor in the success of Akhism system lay in the reflection of moral values on every stage of education (whether it be formal/non-formal, home/work or school/out-of-school). If such an understanding is adopted and applied with determination in today's education system, it is highly likely that the problems experienced in economic and social life will be largely eliminated.

Keywords: Akhism, Values, Management, Education, Values education.

(The Extended Abstract is at the end of the article.)

\section{Giriş}

Ahlaki değerleri göz ardı eden, sadece iktisadi değerleri ön plana çıkaran ve yücelten kapitalizmin etkisiyle son dönemlerde iş hayatı ve sosyal hayatın neredeyse bütün bölümlerinde ahlaki sorunların artarak devam ettiği görülmektedir. Bunun sonucu insanlar mutsuzlaşmakta, sosyal yapılar çözülmekte, işyerlerinde stres, gerginlik ve psikolojik rahatsızlıklar baş göstermekte, sadece kazanmaya odaklı acımasız ve yıkıcı rekabet pek çok örgütün piyasadan silinmesine yol açmaktadır.

Kapitalizm gayr-i ahlaki/seküler yapısı (Zaim, 1992, s. 19), kayıtsız şartsız kazanç eğilimi (Tuna ve Yalçıntaş, 1997, s. 157-158) ve bünyesindeki kültürel çelişkiler nedeniyle gündüz disiplinli, geceleri sefa düşkünü, tüketim ve haz tutkunu, bencil bir insan prototipi ortaya çıkarmıştır (Bell, 1978, s. 206-222). Kapitalizmin türettiği iktisadi düşünen adam (homo-economicus) tipi ile denge, dayanışma ve toplumun mutluluğunu hedefleyen bir sosyal adalet (Es-Sadr, 1980, s.300) anlayışına sahip İslam'ın ortaya koyduğu Müslüman adam (homo-islamicus) tipi (Zaim, 1994, s. 102) arasında değerleri ve hayata yansıması bakımından önemli farklılıklar bulunmaktadır. Müslüman insan, iktisadi düşünen insanın aksine ekonomik yükselme ile birlikte ahlaki yükselmeyi de amaçlayan, sadece kendini değil başkalarını da düşünen, bireysel, sosyal ve ortak sorumluluk sahibi kişidir (Hamitoğulları, 1987, s. 30-31; Mannan, 1989, s. 52).

Batı dünyasında baş gösteren ve küreselleşme ile bütün dünyaya sirayet eden (Köylü, 2006, s. 81-146) sorunlardan kurtulmak, ahlaki değerleri yönetimde etkili kılmak amacıyla 1950'li yıllarda sosyal sorumluluk kavramı gündeme gel- 
miştir (Bu kavramın ilk defa 1953 yılında H. R. Bowenin Social Responsibilities of Businissman isimli eserinde kullanıldığı kanaati yaygındır). Ancak ortaya konan yaklaşımların da beklenen sonuca ulaşmada yetersiz kaldığı görülmektedir. Bunun başlica nedeni olarak ahlaki değerleri yeterince içselleştirememiş, iktisadi değerleri ön plana alan örgütlerin sosyal sorumluluk bildirgeleri ile bu alandaki uygulamalarını pazarlama/çıkar amaçlı kullanmaları gösterilmektedir (Porter ve Kramer, 2005, s. 37). Örneğin; günümüzde ABD'de ilk 500 şirketin büyük çoğunluğu yazılı davranış standartları, etik ofisleri, sosyal muhasebe ve sosyal projelere ilişkin resmi anlaşmaları içeren etik kodlara sahip olduğu halde, bu şirketlerde yaşanan ahlak ihlallerine dair skandallar gazete manşetlerinde yer almaya devam etmektedir. Enron, Tyco, World Com, Adelphia, Parmalat, Ahold vb. şirketlerde yaşanan hileli raporlama uygulamaları bu konudaki örneklerden bazılarıdır (Hamel ve Breen, 2007, s. 22; Mondy, 2017, s.26)

$\mathrm{Bu}$ çalışmanın amacı; asırlarca etkisini sürdürmüş ve performansı ile doğu-batı tüm dünyanın beğenisini kazanmış, günümüzde bile hala kendisinden bahsettiren Ahilik sistemi ile onu ayakta tutan ve etkili kılan değerleri, bu değerlerin eğitimde (insan yetiştirme) nasıl kullanıldığ ve söz konusu başarıya nasıl ulaşıldığını incelemek, günümüz çalışma hayatı ve eğitim uygulamaları (örgün/yaygın) bakımından örnek alınabilecek yönlerini belirlemek ve değerlendirmektir. Literatür taramasına dayalı derleme niteliğindeki çalışma, Ahilik sistemi değerleri ve bu değerlerin işbaşı ve iş dış1 eğitimlerde nasıl kullanıldığ1 ve kişi, örgüt ve toplum üzerindeki etkilerini kapsamaktadır. Çalışma yaklaşımı, konu ile ilgili temel kaynakların yer aldığı geniş çaplı literatürü içermesi ve ortaya koyduğu sonuçları bakımından özgündür.

\section{Değerler, Yönetim ve Eğitim}

\section{Değer Nedir?}

Değer (value) Latincede kıymetli, güçlü olma anlamlarına gelen 'valere'den türetilmiş bir kavramdır (Bilgin, 1995, s. 83). Bir şeyin önemini belirlemeye yarayan soyut ölçü, bir şeyin değdiği karşıllk, kıymet (TDK, Güncel Türkçe Sözlük), önem veya liyakat, kullanışlılık, bir birey veya grubun ilkeleri veya standartları, idealleri anlamlarında kullanılmaktadır (MacMillan, Contemporary Dictionary, 1988, s. 1104).

Değer kavramına yönelik çeşitli tanımlamalar yapılmıştır. Bu tanımları 'birey ya da grupların tercih ve davranışlarını belirleyen standartlar, inançlar' şeklinde 
özetlemek mümkündür (Güngör, 1993, s. 27; Herriot, 1976, s. 18; Kilby, 1993, s. 33; Kluckhohn, 1951, s. 395; Lennick ve Kiel, 2005, s. 44; Rokeach,1973, s. 5; Suparka ve Johnson, 1975 'dan akt. Kaymakcan ve Meydan,2014, s. 24).

Değerler bireylere ve topluma yön veren, davranışları belirleyen ilkeler ve tercihlerdir. Bu ilkeler; tarihi, kültürel, sosyal, ekonomik vb. faktörlere bağl1 olarak oluşur, tercihleri ve davranışları belirler (McCrae, 2004, s. 4; Özensel, 2003, 229; Schwartz, 1994, s. 3; Triandis ve Suh, 2002, s. 133). Değerler, olayları anlamlandırmada ve doğru tutumlar oluşturmada önemli bir etkiye sahiptir (Lennick ve Kiel, 2005, s. 44).

Değerler, kişilerin düşünce ve eylemlerini nitelemeye, değerlendirmeye ve yargılamaya yarayan ölçütlerin kaynağını oluşturur. Değer; eylemi gerçekleştiren, eylemle gerçekleşen ve eylemin gerçekleştiği ortamda ortaya çıar (Poyraz, 2007, s. 83). Değerlerin birey ve toplum üzerinde önemli etkisi bulunmaktadır. Bireyin hem kendisi hem de toplumla uyumlu bir şekilde mutlu ve huzurlu bir şekilde yaşayabilmesi için ortak değerlere ihtiyaç bulunmaktadır.

Değerleri ilgili alanlar veya kültürler göz önünde bulundurmak suretiyle (ekonomik, estetik, ahlaki, dini, siyasal veya kuramsal vb) farklı şekilde sınıflandırmak mümkündür (Güney, 2015, s. 122). Her kültür çevresinde farklı değerlere rastlamak mümkündür. Değerleri içkin (teknik-sanat, fikir), aşkın (din ve ahlak) ve normatif (dil, hukuk, iktisat) olmak üzere üç ayrı kısımda ele almak mümkündür. Bunlardan birincisi duyulara, ikincisi duyular ve duygulara, üçüncüsü her ikisi yardımı ile kavramlara dayanır (Ülken, 2013, s. 298-300). Değerler eğitimi bunların bütününe dayalı olmalıdır.

Değerler toplumu oluşturan bireyleri bir arada tutan, grup/toplumları diğerlerinden ayıran kültürel kodlardır (Durkheim,1986, s. 22-24; Güngör, 1993, s. 27 28). Bu nedenle eğitime konu edilmesi, kuruluş/toplumların geleceği açısından oldukça önemlidir.

Değerler, soyut içeriğe sahip olmalarına rağmen sonuçları somut olmakta ve inandıklarımız ile davranışlarımız arasında bir köprü oluşturmaktadırlar. Başarma arzusu kişilik ile ilgili iken, bunu nasıl gerçekleştirdiğimiz değerlerimiz ile ilgili olmaktadır. Değerler sağlam ise dış faktörlerin baskısı da daha az etkili olmaktadır. Değerler, yöneticilerin günlük eylem ve kararlarında başvurdukları referanslar olarak kabul görmektedirler (Baltaş, 2009, s. 97-106).

Değerler, amaçlar ya da eylemlerin seçiminde motive edici bir etkiye sahiptirler (Dose ve Klimoski, 1999, s. 85). Bir bağlantının değer üretebilmesi için 
ilişkinin değerli olarak algılanması gerekir. Bir şeyi değer olarak görmek, ahlaki açıdan onu bir amacın aracı değil, başlı başına amaç olarak değerlendirmektir (Türkeri, 2011, s. 402).

Değerleri ahlakla ilgili olan ve olmayan olarak ikiye ayırmak mümkündür. Ahlaki değerler emredici bir niteliğe sahipken, ahlaka ilişkin olmayan değerler genellikle kişisel tercihlerle ilgilidir. Ahlaki değerler de evrensel olanlar ve olmayanlar şeklinde iki kategoride değerlendirilebilir.

Ahlaki değerler inançlar üzerine kuruludur, tutum ve davranışlara yön verir, nesnelerin iyi veya kötü olarak tanımlamasını yaparlar. Değerler dizisi günlük hayata yön veren kazanımları ve yasaklamaları oluşturur, çevrede olup bitenlerle nesneleri algılama ve yorumlamaya yardımc1 olur (Boyatzis, 2005, s. xxiv). İslam ahlak bilimcileri de benzer düşünceye sahiptirler (Topçu, 2017, s. 35; Ülgener, 2006, s. 8-10).

İslam inancında iman-ahlak ilişkisi güçlüdür, her ikisi birbirine bağlıdır. Bu anlayışın temelini ahiret inancı ile dengeli bir yaşam sürme ideali (dünya-ahiret dengesi) oluşturur. İslam'a göre değerler insanüstü bir otorite tarafından belirlenmelidir (Yusuf Suresi, 12:40). Aksi takdirde mutlaklığı ve genel kabule şayanlığ 1 tartışmalı hale gelir. İnsanlar eylemleri değerlendirirken sonuçların kendilerine yansımasına bakarlar ve buna göre karar verirler. Bu durum ise karmaşaya neden olur (Çağrıc1, 2013, s. 129).

İlkeler ve değerler birbirinden farklıdır. İlkeler dışsal, değerler ise içseldirler. Eğer ilkelere değer verilirse, olumlu sonuçlar elde edilebilir. Herkesin değerleri vardır ve bunlar kişinin davranışlarını yönetir. Ancak, davranışların sonuçları ilkelerin gözetimi altındadır ve bu nedenle ilkeler önemsenmelidir (Covey,2008, s. 366-367).

Ahlaki değerler toplum/kültürlere göre değişiklik gösterse de evrensel düzeyde genel kabul görmüş, toplumlara göre değişiklik göstermeyen etkinliğini sürdüren ahlaki değerler ve ilkeler bulunmaktadır. Bunları adalet, doğruluk, tarafsızlık ve sorumluluk ana başlıkları altında toplamak mümkündür (Arslan ve Berkman, 2009, s. 32). Birbirleriyle doğrudan ilişkili bu değerler hayatın her alanında olduğu gibi, iş hayatı ve yönetim süreçleri üzerinde de önemli etkiye sahiptirler. Örneğin; doğruluk/dürüstlük dünya'nın her yerinde geçerli olan, gerek iktisadi ve gerekse sosyal hayatta ilişkileri belirleyen en önemli evrensel ahlaki değer olarak bilinmektedir. 


\section{Yönetim ve Değerler}

Yönetim; başta insanlar olmak üzere parasal kaynakları, donanımı, demirbaşlar1, hammaddeleri, yardımcı maddeleri ve zamanı birbiriyle uyumlu, verimli ve etkin kullanabilecek kararlar alma ve uygulatma süreçleri toplamı olarak tanımlanır (Eren, 2011, s. 3). Yönetim faaliyetini gerçekleştiren kişiye ise yönetici denir. Yönetim sürecinin en önemli aktörü insandır. İnsan (sermayedar, yönetici ya da çalışan, pozisyonu ne olursa olsun) yönetim sürecinin etkinliği ve verimliliğinde sahip olduğu ahlaki değerlerle birlikte önemli rol oynar. Bu nedenledir ki, ahlaki sorunların önemli boyutlara ulaştığı günümüzde değerlerle yönetim (Blanchard ve O'connor, 1998) konusu iş ve akademi çevrelerinin önemli gündem maddesi haline dönüşmüş durumdadır.

Değerler, yönetimde kullanılan en önemli araçlardandır. Amaç ve eylemlerin seçiminde yönlendirici ve motive edici bir etkiye sahiptirler (Doğan, Aşkun ve Yozgat 2007, s. 23). Yöneticilerin karar alma ve uygulatma sürecinde bireysel ve örgütsel değerlerin etkisi büyüktür. Örgütsel değerler çalışanların davranışlarını nitelendirme, değerlendirme ve yargılamaya yarayan ölçütlerin temelini de oluşturur (Sabuncuoğlu ve Tüz, 2001, s. 43; Şişman, 2002, s. 95). Bu nedenle de genellikle performans değerlendirme kriterleri arasında yer alırlar.

Organizasyonlarda çalışanlar ve yöneticilerin değerlerinde birtakım farklılıklar söz konusu olabilir. Önemli olan herhangi bir çatışmaya firsat vermeden üye/çalışan değerleri ile örgütsel değerleri uyumlaştırıp bütünleştirmektir. Bu suretle tutum ve davranışları olumlu yönde etkilemek mümkün olur (Ennulo ve Turnpuu, 2001, s. 344; Delgrosso, 2004, s. 26; Eren, 2010, s. 220). Örgütsel değerler yeni üyelere (hatta tüm paydaşlara) aktarılmalı, sistem (başta üst yönetim tarafından olmak üzere) desteklenmeli ve sürdürülebilirliği sağlanmalıdır (Wiener, 1988, s. 541).

Bireysel değerlerle uyumlu, benimsenmiş ortak değerler, örgüt üyelerinin birbirine bağlanmasına, örgütsel bütünleşme ve istikrara zemin oluşturur. Paylaşılan ortak değerler örgüt içi güven ve motivasyonu arttırır, bu suretle de kararlar ve eylemlerin kalitesi yükselir (Argüden, 2004, s. 19). Örgütsel değerler ve buna dayalı yönetim yaklaşımları ile çalışanların örgüte bağlılık, iş tatmini ve örgütsel başarı düzeyi arasında kuvvetli bir ilişki bulunduğu bilinmektedir (Baltaş, 2009, s. 100; Barutçugil, 2004, s. 223-224; Hazlitt, 2002, s. 15; Vurgun ve Öztop, 2011, s. 226; Ştefanescu ve Doval, 2010, s. 36-38; Ünsür, 2020, s. 100-101; Zaim, 2013, s. 193-194) ). Yapılan araştırmalar yönetimde ahlaki de- 
ğerlerin gözetilmesinin karar süreçlerinin etkinliği, ilişkilerin güçlendirilmesi, motivasyonun arttırılması ve işlem maliyetlerinin düşürülmesinde önemli rol oynadığını ortaya koymaktadır (Demir, 2002, s. 3-7).

Örgütsel değerlerin etkinliği benimseme ve uyum ile ilgilidir. Yönetim politikaları ile yönetici yaklaşımları bu konuda belirleyici rol oynar. Ahlaki değerlere dayalı bir yönetim tarzının (değerlerle yönetim) organizasyonlarda bağlılık, güven, huzur ve heyecan oluşturduğu, performans ve başarıda önemli etkisi bulunduğu görülmektedir. Bu nedenle örgüt politika ve stratejileri ahlaki değerleri destekleyen ve güvence altına alan bir niteliğe sahip olmalı, buna uygun atmosfer (örgüt iklimi) oluşturulmalı, ahlaki değerler tanımlanmış ve bilinirliği sağlanmış olmalı, yönetimin en önemli aktörü olan yöneticiler ahlaki (genel) ve örgütsel değerleri özümsemiş olanlardan seçilmeli ve buna uygun olarak yetiştirilmeli, işe alımlarda örgüt kültürüne uyum sağlayabilecek bireyler tercih edilmelidir. Üst yönetimin ise bu konuda öncü ve örnek (destekleyici) bir rol oynaması politika ve yaklaşımların etkinliği açısından oldukça önemlidir.

\section{Değerler ve Eğitim}

Eğitim; çocukların ve gençlerin toplum yaşayışında yerlerini almaları için gerekli bilgi, beceri ve anlayışları elde etmelerine, kişiliklerini geliştirmelerine, okul içinde ve dışında doğrudan veya dolaylı yardım etme, terbiye anlamında kullanılan bir kavramdır (TDK, 2019). Bir başka ifade ile eğitim; kişi ya da grupların üstlendikleri ya da ileride üstlenecekleri görev veya sorumlulukları daha etkili bir şekilde yapabilmeleri için ufuklarını genişleten düşünce, rasyonel karar alma, davranış ve tutum, alışkanlık ve anlayışlarında olumlu değişmeler amaçlayan, bilgi, görgü ve yeteneklerini arttıran eğitsel faaliyet ve eylemlerdir (Aydın, 2003, s. 139; Sabuncuoğlu, 2011, s.124; Özçelik, 2013, s. 165).

Her ülkenin eğitim sistemini o ülkenin sosyal ve kültürel değerleri belirler (Cramer ve Browne, 1977, s. 23). Eğitimin amac1, kişiye bilgi ve beceri kazandırma, duygu ve davranışlarını düzenleme ve ahlaki karakter kazandırmaktır (Çamdibi, 1983, s. 13; Kerschenstainer, 1977, s. 8). Ahlaki karakter insanın kişiliğinde var olan eğilimlerin aile, din ve eğitim kuruluşları vb. tarafından şekillendirilmesi sonucu oluşur (Andrews, 2005, s. 73; Eren, 2010, s. 84) ve insan onurunu koruyan, ilahi kaynaklarda ve toplumun ortak mirasında yer edinen değerlerin birey tarafından içselleştirilerek kalıcı hale getirilmesi ile ortaya çıkar (Kaymakcan ve Meydan, 2014, s. 41). 
İş ve meslek bakımından değerlendirildiğinde; eğitim, işle ilgili yetkinliklerin çalışanlar tarafından kazanılması için kuruluşlar tarafindan planlanmış faaliyetleri ifade eder (Noe, 1999, s. 4; Ülken, 2013, s. 182). Buna göre eğitim, çalışanların iş performansı için gerekli bilgi, beceri, tutum ve davranışları kazandırma ve geliştirme sürecidir. Amacı ise, çalışanlara işlerini daha başarılı bir şekilde yerine getirebilmeleri için gerekli, günün şartlarına uygun bilgi, beceri ve yetenekleri kazandırmaktır. Eğitimle kazanılan bilgi, beceri ve davranışlar organizasyonların entelektüel sermayesini oluşturur ve eğitim bireysel performansla birlikte örgütsel performansı da etkiler (Kelly, 1987, s. 22). Eğitimin en önemli güçlendirme aracı olduğunda herhangi bir şüphe yoktur. Ancak, eğitimle kazanılan gücün sağlıklı bir şekilde kullanımında ahlak/değerler eğitimi önemli rol oynar (Kaymakcan ve Meydan, 2014, s. 137).

Ahlak, insan davranışlarını yöneten/yönlendiren ideal kuralların ilmi ve bunları hayatın çeşitli durumlarına en iyi şekilde uygulayabilme sanatıdır (Pazarlı, 1972, s. 13). Ahlak olgusu, herkese kendini içten ve dıştan kabul ettiren evrensel bir gerçektir (Gregoire, 1971, s. 17).

İş ve meslek ahlakı, toplumun o iş ve mesleğe ilişkin değerler ve tutumlarını ifade eder. (Arslan ve Berkman, 2009, s. 36). Mesleki ahlak kuralları (mesleki değerler), kişilerin mesleklerini icra ederken ideoloji, kültür ve dünya görüşlerinden bağımsız olarak uymaları beklenen ilke ve değerlerdir (Kuçuradi, 2003a, s. 16).

Ahlaki değerleri koruyarak yaşayabilmek ve meslekleri buna uygun yapabilmek için değerlere dayalı bir eğitime ihtiyaç vardır (Kuçuradi, 2003b, s. 9). Eğitimin en önemli amaçlarından biri kişiye ahlaki karakter kazandırmak ve onu davranış hale dönüştürmektir (Berkowitz, 2011, s. 153).

Ahlaki değerlere uygun davranmaya ahlaki davranış denir. Ahlaki davranış iyi ve kötü hakkında gerekli bilgi ve donanımı, olabildiğince kötülükten arınmış ve iyilikle bezenmiş bir benliğe sahip olmayı, kötülükten kaçınma ve kaçındırmakla birlikte elden geldiğince iyilik yapma ve iyilikte yardımlaşmayı, kötülüğün yayılmasını önleme ve iyiliğin yayılması için gerekli çabanın gösterilmesini ifade eder (Yaran, 2015, s. 73-80). Ahlaki davranış, akıl ve irade sahibi kişinin hür iradesi ile iyilik amaçlı bilinçli davranışlarıdır (Kaymakcan ve Meydan, 2014, s. 21). Ahlaki davranışlar ölçülü olmayı, mutedil kalmayı gerektirir (İşlerin en hayırlısı orta-ifrat ve tefritten kaçınma-olanıdır, Acluni, Keşf-ül Hafa, C. 1, 391). Ahlaki davranışlar bireyin gelişim düzeyi, içinde bulunduğu şartlar, demografik özellikler, ekonomik durum, ahlaki ve kültürel değerlerden etkilenir. 
Ahlaki davranış, akıl ve irade sahibi kiş̧inin özgürce hayır amaçlı yaptığı bilinçli hareketlerdir (Pazarl1, 1972, s. 43-45), aynı zamanda sevgi, adalet ve cesaret gibi değerlerle doğrudan ilişkilidirler. Ortada korku, zorlama ve haksızlık varsa bu tür davranışların ahlakiliğinden söz edilemez. Ahlaki davranışlar bireyin gelişim düzeyi, içinde bulunulan şartlar, demografik özellikler, ekonomik durum ve değerlerden etkilenir (Ünsür, 2018, s. 11).

Ahlaki davranışların temelinde ideal bir beğenme bulunur. $\mathrm{Bu}$ ideal beğenme hürriyete dayalı ahlaki seçimi gerektirir. Bu nedenle ahlaki seçimde akla uygunluk esastır. Ahlaki davranışlarda aranan akla uygunluk, başkalarının tecrübeleriyle birleşme anlamında anlaşılmalıdır. Onda evrensellik yoktur, ancak evrensele yönelme istidadı vardır. Aile, meslek grubu, millet gibi oluşumlar bu suretle gerçekleşir. İkinci bir özellik, ahlaki tercihlerin ideal oluşudur. İdeal değerler başkalarının da beğenisini cezbeder. Üçüncü özellik, sarsılmaz oluşudur. Kişiye hem içeriden hem de dişarıdan baskı yaparlar. Dördüncü özellik etkinliktir. Ahlaki fiil sadece ideal bir beğenme ve seçme ile tamamlanmaz, aynı zamanda başkalarına da kabul ettirmek şeklinde genelleşmeye de mecburdur (Ülken, 2001, s. 22-25).

Değerler eğitimi ile kişilik sahibi, dürüst ve ahlaklı bireyler yetiştirmek mümkün olur. Bunun için tam bir güven ile temiz bir kalbe ihtiyaç vardır (Bertrand, 2001, s. 2). Bu nedenle maddi-manevi uygun ortamlar oluşturulmalıdır (Çağlayan, 2005, s. 92-93).

Değerler eğitiminin sadece okulda değil, hayatın akışı içinde verilmesi en uygun yöntemdir. Böylece kazandırılmak istenen değerlerin doğal bir süreçte sosyal öğrenme yoluyla edinilmesi sağlanabilecektir (Hökelekli ve Gündüz, 2007, s. 389). Bu yaklaşım değerlerin önemini kavramayı, örnek olmayı, ahlaki sorumlulukların farkına varmayı ve buna göre davranmayı gerekli kılar.

\section{Ahilik Sistemi, Değerleri ve Eğitimi}

\section{Ahilik Nedir?}

Ahi Arapçada kardeş, kardeşim anlamına gelen uhuvvet kelimesinden türetilmiş bir kelimedir. Türkçe bir kelime olan ve eli açık, cömert anlamına gelen $a k ı$ kelimesinden türemiş olduğu da ifade edilmektedir (Kazıcı, 1988, s. 540; Çağatay, 1997, s. 44). İster İslam'ın temel ilkelerinden kardeşlik (Hucurat Suresi, 49:10), isterse cömertlik (İsra Suresi, 17:29) kelimelerinden türetilmiş olsun 
ahilik modelinin, akılık (cömert) felsefesi ile İslami fütüvvet anlayışının bütünleşmesi sonucu ortaya çıktığı anlaşılmaktadır (Bayram, 1995, s. 29; Ocak, 1996, s. 261-263). Ahiler tarik-ı fütüvvete süluk ve akd-i uhuvvet eden bir zümrenin ünvanıdır (Ahmed Rif'at, 1881, C. 1, s. 106) ifadesi de bunu doğrulamaktadır. Ahiliğin uhuvvet (kardeşlik) duygusuna dayalı (Hamitoğulları, 1986, s. 13; Pekolcay, 1986, s. 77) dayanışma esaslı bir esnaf birliği olduğu konusunda yaygın bir kanaat bulunmaktadır (Ekinci, 2008, s. 19; Wittek, 1971, s. 37).

Ahilik dürüstlük, güvenirlik, çalışkanlık gibi ahlaki erdemlerle, meşru bir iş ve mesleğe sahip olma, nitelikli üretim ve helal kazanç elde etme arzusu gibi ideallerin birbiriyle bütünleştiği çift yönlü bir sistemdir. Buna göre Ahiliği, inancın bilgi ile beslenmesi ve çalışma ile şekillenmesi şeklinde tanımlamak mümkündür (Soykut, 1980, s. 17).

Ahilik kaynağı İslam olan, ahlaki değerleri hem çalışma hayatına hem de sosyal hayata hakim kılmayı, erdemli ve üretken bireyler yetiştirmeyi amaçlayan bir modelin adıdır. Ünlü gezgin İbn-i Battuta Seyahatnamesinde Ahiler için dünyada bunlardan daha iyi kalpli, iyi davranışlı kişiye rastlamadım demiştir (TESK, 1973, s. 31-33).

Ahilik sisteminde çıkar çatışması bulunmaz, herkes ortak çıkar (Allah'ın rızasını kazanmak) etrafında birleşmiştir. Ahilik, yıkıcı rekabeti, sadece kar için çalışmayı kibir alameti olarak değerlendirmiş ve aşağılamıştır (Faroqhi, 2011, s. 84). Ahilikte ahlak bütün süreçlerin merkezine oturtulmuş, aynı şartlarda çalışan ve aynı mal ya da hizmeti üreten bir işyerinde kalite ve verimliliği sağlayacak işgücünün ayırıcı özelliği olarak değerlendirilmiştir (Araz vd., 1994, s. 132).

Ahiliği, yönetiminde değerler ve kaliteyi esas alması nedeniyle bir değerlerle yönetim, eğitimde değerleri esas alması nedeniyle de değerlerle eğitim kuruluşu olarak nitelendirmek mümkündür. Japonların, E. Deming'in (1900-1993) meşhur PUKÖ (planla-uygula-kontrol et-önlem al) döngüsünü esas alan hoshin kanri yönteminin Ahilikle benzer yönleri bulunmaktadır (Akao, 1999, s. 20). Günümüz modern yönetim yaklaşımlarından olan toplam kalite yönetiminin de Ahilik uygulamaları ile benzeşen önemli yönleri bulunduğu (örneğin; müşteri ilişkileri, üretim felsefesi, grup bilinci, paydaş memnuniyeti vb.) nihai hedefin de Ahilikte olduğu gibi toplumsal huzuru sağlamak olduğu görülmektedir (Şimşek, 2000, s. 131). Ahiliğin mesleki eğitim boyutunun iş birliğine dayalı Alman mesleki eğitim sisteminin oluşumuna katkı sağladığı değerlendirilmektedir (Greinert, 1996, s. 6-12; Klause, 1996, s. 13-17). 
Ahilikte meşru bir iş ve meslek sahibi olmak, emek sarf edilerek kazanç elde etmek zorunludur. Gücü kuvveti varken çalışmamak ve aylaklık etmek, akılsızlık ve ahlaksızlık olarak nitelendirilmiştir (Ekinci, 2008, s. 23). Hayat felsefesi olarak dünya-ahiret dengesi (Ramuz-ul Ehadis, C. 1, 282) esas alınmıştır. İslam'ın emeğe verdiği değerin bir nişanesi olan bu anlayış1 Ahiliğin toplumun en önemli dinamiklerinden biri olarak işlev gördüğ̈̈ dönemlerde Osmanlı Sultanları'nda da görmek mümkündür. Padişahlardan her birinin birer meslek ve sanat sahibi olduğu bilinmektedir (Lewis,1973, s. 146).

Ahilerin kurduğu esnaf ve sanatkâr birlikleri İslam'ı esas alarak oluşturdukları kurallarla sistemin omurgasını oluşturmuşlar, ilk yıllarda debbağlık (dericilik) ile öne çıkan sistem, ihtiyaç merkezli olarak otuz iki ayrı meslek grubuna kadar yaygınlık kazanmıştır. Ahilik sağlam bir mesleki ve ahlaki düzen, birbirine bağlılık, yardımlaşma ve dayanışma duyguları ile ön plana çıkmıştır. Ahiliğin ahlakla sanatı bütünleştiren bir kurum olduğu konusunda yaygın bir kanaat bulunmaktadır (TESK, 1973, s. 27).

İslami değerleri esas alan bir mesleki örgütlenme biçimi olan ve insanları yararlı mesleklere yönelten Ahilikte bazı mesleki gruplar üyeliğe kabul edilmemiştir. Avcılar, kasaplar ve meyhaneciler bunlar arasında yer almaktadır (Faroqhi, 2011, s. 69).

Ahilik aynı zamanda tasavvufi yönü ile ön plana çıan bir sistemdir. Orhan Gazi döneminde Anadolu'yu gezen ünlü seyyah İbn Battuta, Ahi birliklerinin şehir ve taşrada örgütlenen sanat ve ziraat ehli topluluklar olduğunu belirmekte ve tasavvufi hayatla iç içe olan ilişkilerine işaret etmektedir (Kazıcı, 1988, s. 541; Köprülü, 1981, s. 213). Sufiler (tasavvuf erbab1) temel ahlaki değerleri ve faziletleri fütüvvet kelimesine yükleyerek onu tasavvufun temel kavramlarından biri haline getirmişlerdir (Kütükoğlu, 1986, s. 55; Uludağ, 1996, s. 261). Tasavvuf erbabına göre fütüvvet $\mathrm{Hz}$. Muhammed (SAV)'den kalan bir ahlak yoludur. Toplumun huzur ve rahatı için her zaman gerekli olan iyi huylar ve davranışlar, can güvenliği ve insanlığa saygı demek olan yiğitlik, cömertlik ve misafirperverlik fütüvvetin temelini oluşturmaktadır (Çağatay, 1994, s. 105).

Fütüvvet teşkilatları Abbasi Halifesi Nasır Li Dinillah (1180-1225) zamanında devlet desteği ile güçlenmiş, diğer Müslüman toplumlara yayılmaya başlamıştır. I. Gıyaseddin Keyhüsrev (1205-1211) zamanında Anadolu Selçuklu Devleti ile temaslar kurulmuş, bu kapsamda Evhadüddin Kirmani, Muhiddin İbn-i Arabi ve Şeyh Nasruddin Ebu-1 Hakayık Mahmud b. Ahmed El Hoyi (Ahi Evran) Anadolu'ya gönderilmiştir. Selçuklu hükümdarlarından I. İzzettin Key- 
kavus ile I. Alaaddin Keykubat'ın fütüvvet teşkilatına kaydoldukları (Kazıcı, 1988, s. 540), 13. yüzyıldan itibaren üst düzey devlet adamları ile birlikte ilim ve ticaret erbabının da teşkilata katıldığı, bu nedenle de Ahiliğin itibar ve statüsü yüksek bir kurum haline geldiği görülmektedir (Tabakoğlu, 2008, s. 43). Fütüvvet temelli Ahilik Anadolu'da özellikle I. Alaaddin Keykubat (1220-1237) zamanında etkinlik kazanmış, Ahi Evran öncülüğünde şehir, kasaba ve köylerde örgütlenmiş siyasi, sosyal, kültürel ve iktisadi hayata damgasını vurmuştur. Osmanlı Devleti döneminde de bu etkinliğini sürdürmüş, 13.-20. yüzyıl arası Anadolu Esnaf ve Sanatkârlar Birliği olarak faaliyet göstermiştir.

Ahi Evran (1171-1261) ahlak, sanat ve misafirperverliğin uyumlu bir bileşimi olan Ahiliği kurmuş, bu kurum kazandığı saygınlık ve beğeni nedeniyle yüzlerce yıl iş hayatı yanında sosyal yapının güçlenmesi ve istikrarında önemli roller oynamış, yeniçerilik gibi birtakım kuruluşların oluşumuna rehberlik etmiştir (Çağatay, 1997, s. 50). Ahiliğin Batı toplumlarında birtakım örgütlenmeler (sendika, meslek odası, kooperatif vb.) için de örnek oluşturduğu ifade edilmektedir (Gülerman ve Taştekil, 1993, s. 5-9).

İlke ve değerlerini İslam dininden alan Ahi töre ve törenleri ile sisteme giriş kurallarını içeren Ahilik nizamnamelerine fütüvvetname adı verilmiştir (Çağatay, 1997, s. 1). Fütüvvetnamelerde Ahiliğin esasları, ahlaki ve ticari kurallar tanımlanmıştır. Sisteme dahil olacak kişilerin belirtilen kuralları bilmek ve bunlara uyması zorunlu kılınmıştır. Buna göre; teşkilat mensupları doğruluk, vefa, emniyet, cömertlik, tevazu, ihvana nasihat, onları doğru yola sevk etme, affedici olma ve tövbe gibi ahlaki özelliklere sahip olmalı içki, zina, yalan, gıybet, hile gibi davranışlardan sakınmalı idiler. Ahlak dışı davranışlar meslekten atılmayı gerektirmekte idi (Kazıc1, 1988, s. 541; Kütükoğlu, 1986, s. 60). Ahi füvvetnamelerinden bazıları şunlardır (Ünsür, 2017, s. 92);

- Sühreverdi Fütüvvetnamesi (Kitab-ul Fütüvve, Risale-i Fütüvve),

- Sufi Fütüvvetnameleri (örneğin, Kuşeyri Risalesi),

- Burgazi/Çobanoğlu Fütüvvetnamesi (Yahya b. Halil Çoban el Burgazi),

- Radavi Fütüvvetnamesi (Miftah-ud Dekaik fi Beyan el Fütüvve ve-1 Hakaik).

Ahilik, 12. ve 13. asırların harp, isyan ve istila dalgaları arasında sanat erbabı için dinlendirici, huzur ve güven verici bir ocak başı fonksiyonu icra etmiştir. $\mathrm{Bu}$ nedenle, ahi zaviyelerine sadece bir iktisadi teşekkül olarak değil, üyeleri arasında sıcak ve samimi bir topluluk ruhunun tecessüm ettiği, kristalleştiği bir yapı olarak bakmak gerekir (Ülgener, 2006, s. 67). Bu topluluk ruhu (cemaat/ 
community) üyelerini değerler çizgisinde kalmaya, onları bu çizgiden uzaklaştıracak tehlikelerden korumaya yönelik bir kalkan vazifesi görmüştür.

Ahiler bir sanat ve meslek topluluğu olmalarına karşın, iktisadi yönlerinden ziyade dini, içtimai ve politik değerleri bünyesinde toplayıp bir araya getirmekle tanınmışlardır. İbn-i Battuta'nın ahilerde görüp hayranlıkla bahsettiği mesleki kabiliyetlerden ziyade, aralarındaki samimiyet, dayanışma ve misafirperverlik anlayışının daha dikkat çekici boyutlarda olduğu bilinmektedir (Ülgener, 2006, s. 64).

Ahilikte mal ve servet gibi çalışma da tek başına bir değer taşımadığı, ancak daha anlamlı ve değerli amaçlar için kullanıldığında bir değer ifade ettiği görülmektedir. Ahilik değerlerinin kişiyi yücelttiği inancı daima belirleyici olmuştur. Yahya b. Halil Fütüvvetnamesinde yer alan şu ifade bu anlayışı desteklemektedir: Şöyle bilin ki ey kardeşler ve azizler! Fütüvvet a 'la ve şeriftir, ulu makamdır. Fütüvvetin aslı imandır. Fütüvvet sıfatı ile kim sıfatlana, ol kişi Allah'a erişmiş olur.

Ahilikte tasavvuf ahlakı, aslında el işçiliğine has dünya görüşünün biraz daha güçlü olarak ifade edilmesinden başka bir şey değildir (Ülgener, 2006, s. 94). İslam'ın el emeği karşılığı elde edilen kazancı yücelttiği anlayışı (Necm Suresi, 53:39) bu yaklaşıma kaynaklık etmiştir. Esnafın dükkanlarında asılı olan $E l$ Kasibu Habibullah (El emeği ile helalinden kazanan Allah'ın sevgisini kazanır) levhaları bunu göstermektedir.

Ahilikte sanatkarlık/el işçiliği ani kazançların çok üstünde bir değer olarak görülmüştür. El işçiliği, bilgi ve yeteneğin yanında sabır gibi erdemleri de gerektirdiğinden sahibini kanaat, sabır ve tevekküle yönlendirmek suretiyle terbiye edici ve nefsani arzuları dizginleyici bir niteliğe sahip olmuştur. Mevlâna Cami, el işçiliğinin nefis terbiyesi ve sslahı için bir törpü olduğunu ifade etmiştir (Ülgener, 2006, s. 95).

Ahi Fütüvvetnamelerinde her ahinin mutlaka bir işi/mesleğinin olması gerektiği vurgulanmıştır. İş ve meslek sahibi olmamanın, kişiyi ihtiyaçlarını gayr-i meşru yollardan karşılamaya sevk edeceği inancı hâkim olmuştur. Gazali (ö. 1111) de iş ve meslek sahibi olmanın kişiye hem dünya hem de ahiretini imar etme firsatı vereceğini vurgulamıştır. Ahilikte, çalışma ilişkilerinde mesleki bilgi (yetkinlik) yanında adalet ve ihsan (Nahl Suresi, 16:90) gözetilmesi gereken ilkeler/değerler olarak görülmüş, dünya-ahiret dengesi (Sizin en hayırlınız dünyası için ahiretini, ahireti için de dünyasını terk etmeyeninizdir, Ramuz-ul Ehadis, C. 1: 282) anlayışı davranışlar açısından belirleyici rol oynamıştır (Çağrıcı, 2013, s. 277-280). 
Ahilik, ana politikaları aynı olmakla birlikte her sanat ve kademenin kendine mahsus örf ve adetleri, merasimleri, davranış ve yaşayış kurallarının bulunduğu bir sistem olarak dikkati çekmektedir. Üretim tarz ve teknikleri de birbirinden farklı bir yapıya sahiptir. Alttan üste (yiğit, ahi... şeyh) doğru hiyerarşik bağl1lık ve teslimiyet söz konusudur. Bu bağlılığın sadece mesleki ve örgütsel anlamda değil, ortak değerler etrafında bütünleşmek suretiyle Allah ve Resulü'nün r1zasını kazanmaya yönelik olduğu görülmektedir. Evliya Çelebi bu durumu şu ifadelerle özetlemektedir; Silsile-i fütüvvet birbirinden biat ile ta Hazret-i Resul'e, andan Hazret-i Cibril'e, andan da Cenab-ı Hakk'a varır (Evliya Çelebi, 1898-1902, C. 1, s. 504)

Özetle; Ahilik temelinde İslam'ın temel değerlerini esas alan, ahlaki değerlerin başta çalışma hayatı olmak üzere hayatın bütün alanlarına yayılması ve etkin kılınmasına zemin hazırlayan bir sistemin adıdır. Sistemin etkin olduğu dönemlerde yönetim, eğitim, çalışma hayatı ve sosyal hayat üzerindeki etkinliği ve performansının oldukça yüksek olduğu anlaşılmaktadır. Sistem bu özelliği nedeniyle günümüz iktisadi ve sosyal sistemlerinin ortaya çıkardığı sorunlara çözüm yaklaşımları bakımından mutlaka değerlendirilmelidir.

\section{Ahilik Sisteminin Değerleri}

Ahilik sistemi değerleri fütüvvetnamelerde tanımlanmıştır. Fütüvvetnameler üyelerin manevi ve sosyal yönlerini geliştirmek amacıyla kullanılmıştır. Fütüvvetnamelerde yer alan ilke ve değerlerin İslami unsurları içerdiği görülmektedir. Kuşeyri (1966) bu durumu fütüvvetin asl daima dini gözetmek, sünnete uymak ve Allah'ın Peygamberine emrettiği şeye tabi olmaktır şeklinde ifade etmiştir. İslam'ın evrensel bir din olduğu (Al-i İmran Suresi, 3:19) ve değerlerinin de evrensel değerler olduğu düşünüldüğünde, Ahilik eğitim sisteminin temelini evrensel değerlerin oluşturduğu rahatlıkla söylenebilir.

Fütüvvetnamelerde yer alan ilke ve değerlerin tamamı 740 tanedir. Şeyh rütbesine çıkanlar bunun tamamını öğrenmek, uygulamak ve başkalarına da öğretmekle yükümlü kılınmıştır. Yeni üyelerin bunlardan belirlenmiş en az 124 tanesini bilmesi ve benimsemesi gerekli sayılmıştır. Ahlaki bakımdan yeterli olmak işe girişte ön şart olarak belirlenmiştir (Çağatay, 1997, s. 163; Muallim Cevdet, 1919, s. 155-156).

Kuşeyri (1966) ve Sülemi (1977)'ye göre fütüvvet güzel ahlak, terbiye ve nezaket olarak ifade edilebilir. Fütüvvet; her türlü kötülüğü terk etmek, güzel 
huylara sahip olarak gereğince davranmaktır (Sülemi, 1977, s. 24). Konu ile ilgili otoritelerden bazılarının fütüvvetle ilgili tanımlamaları şu şekildedir: Cafer-i Sadık; fütüvvet yemek vermek, ihtiyaç sahiplerine malindan bolca vermek, güler yüzlülük, iffet (utanma) ve başkalarına eziyet etmemektir (Sülemi, 1977, s. 52). Yahya ibn Muaz; fütüvvet safa, cömertlik, vefa ve hayadır (Sülemi, 1977, s. 70). Huzeyfe el-Mar'a; fütüvvet dört şeydir gözün, kalbin, dilin ve hevan. Gözünü helal olmayana bakmaktan koru, dilinle sadece doğru söyle, kalbinde bir Müslümana karşı aldatma ve kin bulundurma, heva (nefs)'nın da şerre yönelmemesine dikkat et (Sülemi, 1977, s. 76).

Sülemi Tasavvufta Fütüvvet isimli eserinde fütüvvetin değerlerini şu şekilde sıralamıştır; doğruluk, vefa, cömertlik, güzel huy, göz tokluğu, dostlarla şakalaşma, arkadaşlarla iyi geçinme, kötü söz dinlemekten kaçınma, iyilik yapmayı arzulama, güzel komşuluk, güzel konuşma, ahde vefa, Allah' in senin emrinin altına verdiği aile efradına ve hizmetçilere iyi muamele, çocukları terbiye etme, büyüklere karşı edepli davranma, kinden, aldatmadan, buğzdan uzaklaşma, Allah için dost ve Allah için düşman olma, malını, mevkiini dostlara bezletme, buna karşılık onların başlarına kakmama, malında ve mevkiinde kendisinden yardım dileyenin sözünü yerine getirme, misafirlere hizmet etme, dostların işini gönülden yapma, dostlarına yemeğinden yedirmek suretiyle saygı gösterme, canıyla malıyla onların ihtiyaçlarını karşılamağa koşma, kötülüğü iyilikle karşlama, gelmeyene giderek karşı1ık verme, tevazuya sarılma, kibirden kaçınma, hallerini ve sebeplerini beğenmeden vazgeçme, ana-babaya iyilik, akrabayı ziyaret, ihvanın kusurlarına göz yumma, kabahatlerini örtme, gizlide onlara öğüt verme, her zaman onlara dua etme, halkı yaptıkları işlerde mazur görme, nefsinin şerrini ve zulmünü bilerek her zaman kendini ayıplama, halk ile ülfet etme, Müslümanlara şefkat, merhamet ve iyilik etme, fakirlere acıma, zenginlere şefkat, alimlere tevazu, işittiğinden hakkı kabul etme, dili yalandan, giybetten, kulağı hata işitmekten koruma, gözü haramdan yumma, amellerde ihlas, hallerde doğruluk, dışa dikkat etme, içi gözetme, yaratıklarda iyilik görme, iyilerle arkadaş olma, kötülerden kaçma, dünyadan yüz çevirme, Allah'a yönelme, dilekleri (süfli arzular)terk etme, fani dünya için böbürlenme arzusunu atma, fakirlerle oturmaktan şeref duyma, zenginlere zenginliklerinden dolayı hürmetten kaçınma, Rabbiyle zengin olma ve zenginliğine şükretme, hiç kimseden çekinmeden hakkı söyleme, sevinecek şeye şükretme, belalara sabretme, hiyanetten uzaklaşma, mecliste aşağıda oturmaya razı olma, kendi haklarını istemekten vazgeçme, başkalarının haklarını tam verme ve nefsinden bunu yapmasını isteme, gizlide Allah'ın yasaklarına uyma, arkadaşlara danışma, yokluk sırasında yalnız 
Allah'a güvenme, az tamah, salihlere hürmet, günahkarlara şefkat etmeyi bilme, kimsenin kendisinden rahatsız olmamasına, dışının içine uymasına dikkat etme, dostunun dostuyla dost, düşmanıyla düşman olma, dostunun ziyaretine gideceği kimsenin uzakta bulunması dolayısıyla ziyaretten geri kalmama (Sülemi, 1977, s. 93-94).

Fütüvvetnamelerde yer alan ahi ahlakının temel değerlerini şu şekilde özetlemek mümkündür;

- Yetkinliklerine uygun meşru bir iş ve mesleğe sahip olmak

- Usta nezaretinde sanatın inceliklerini öğrenmek ve korumak (sanatın sırrını herkesle paylaşmamak)

- Birden fazla işe meyletmemek

- Mesleğinde sebat etmek, ilerlemek için çaba göstermek

- Her konuda dürüst olmak

- Hırs etmeyip kanaatkâr olmak

- Teslimkar ve vefakâr olmak (sanatında ve davranışlarında ustası ve mesleğin pirlerini örnek almak)

- Bilgili olmak, bilginleri sevmek (bilgilerini yeri ve zamanında kullanmak, gerektiğinde paylaşmak)

- İşi ve mesleği ile gurur duymak (aidiyet), kolektif şuura sahip olmak

- Ürünü mesleğin yüzünü ağartacak kalitede olmak

- Kimseyi incitmemek (Fütüvvet oldur ki; insan veya hayvan hiç kimse ondan incinmeye, gözsüz, dilsiz, kulaksız, elsiz ve ayaksı gibi ola)

- Misafirperver, cömert, mütevazi ve ahlaklı olmak (Kınalızade, C. 1, s. 157; Ülgener, 2006, s. 57-120).

Görüldüğü gibi, fütüvvetnameler temelini Kur'an ve Sünnetin oluşturduğu Ahilik değerlerini içeren dokümanlardır. Sistemin temel dinamiği konumunda bulunan ahlaki değerlerin ihtiyaca ve şartlara göre ilgililerle ilişkilendirildiği, bütünselliğinin ise daima korunduğu anlaşılmaktadır.

Değerler dokümanı olarak ahi fütüvvetnamelerine yeterince benzememekle birlikte, günümüzde özellikle büyük ölçekli sınırlı sayıda kuruluşun oluşturduğu etik kod (ahlak bildirgesi) uygulamaları da aslında değerlerin en azından örgütsel davranış1 yönlendirmeyi amaç edinmesi bakımından önemli bir gelişme olarak değerlendirilebilir. 


\section{Ahilik Sisteminde Değerler Eğitimi}

Ahilik insanı önceleyen, onun değerlerle yücelebileceğini öngören (Buhari, Edeb, 38, 39) bir değerler eğitimi kurumudur. Mesleki ve genel eğitim uygulamalarında bu durum açıkça görülmektedir. İşyeri ve zaviyelerle yaren odaları vb. ortamlarda genel ve mesleki değerlerin eğitimi süreklilik arz eden bir şekilde yürütülmüş, sonucunda dindar, ahlaklı, mesleğinde yetkin, kendisini sürekli geliştiren, sorumluluk duygusuna sahip iyi bir iş insanı ve iyi bir yurttaş yetiştirmek hedeflenmiştir. Fütüvvetnameler incelendiğinde bu anlayış açıkça görülmektedir. Milli Eğitim Temel Kanunu'nda da benzer amaçların belirlendiği görülmektedir (Resmi Gazete, 24 Haziran 1973, Sayı: 14574).

Değerler eğitimi toplumları başarıya ve geleceğe güvenle taşımada en önemli araçlardandır. Örneğin, 1990’lı yıllarda dikkatleri üzerine çeken Japon başarısındaki ana faktör geleneksel ahlak ilkesi dotoku'ya dayalı eğitim sistemi olduğu bilinmektedir. 1947 tarihli Eğitim Temel Kanunu'nda değerlerine bağlı, dürüst, sorumluluk duygusuna sahip ahlaklı bireyler yetiştirilmesi hedeflenmiştir (Güvenç vd., 1998, s. 17-60).

Ahilikte eğitimle kazanılan bilgi en önemli değer olarak görülmüş, bilgisiz ve bilinçsiz davranışlardan kaçınılması öğ̈̈tlenmiştir. Değerler eğitimi ile elde edilen bilgiye dayalı davranışlar ise övülmüştür. Ahi Evran Letaif-ul Hikme adlı eserinde ilmin amelden önce geldiğini, ilimsiz amelin fayda sağlamayacağını, kişinin ilmini uyguladığı sürece değer kazanacağını ifade etmiştir (Bayram, 1995, s. 38).

Ahi Evran Anadolu'ya geldiğinde dönemin sultanına devletin vatandaşlarını eğitime, özellikle de mesleki eğitime yöneltmesini tavsiye etmiş, kendisine sağlanan destekle insanların çeşitli sanat dallarına yönelmesini sağlamış, bu suretle de göçebe Türkmenlerin yerleşik hayata geçmesine katkıda bulunmuştur. Kendisi de debbağ (dericilik) mesleğini icra ederek sisteme liderlik etmiş, ahilerin mesleki eğitimleri yanında dini ve ahlaki eğitimleri ile yakından ilgilenmiş, bu konuda birtakım eserler kaleme almıştır. Bunlardan Menahic- $i$ Seyfi Anadolu'da kaleme alınan ilk ilmihal olarak bilinmektedir (Bayram, 1981, s. 50 ve 1995, s. 41). İslami değerleri esas alan mesleki eğitim yanında halk eğitimine de verdiği önem nedeniyle Ahi Evran Anadolu’nun Müslümanlaşmasında önemli rol oynamıştır.

Ahi Evran’ın lider kişiliği ve eğitimci vasfı sisteme dahil bireyler ve toplumun diğer katmanları üzerinde önemli etkiler sağlamış, eserleri yıllarca okunmuştur. İslam'ın eğitim politikasını esas alan bu dönemde medrese ve mekteplerin de 
yaygınlaştığı, varlıklı kişilerin bu alanda önemli yatırımlar yaptığı görülmektedir (Sevinç, 1992, s. 130-139).

Ahilik esas olarak işgücünü yeteneklerine göre istihdam eden, onları kişisel ve mesleki olarak eğitip geliştiren, kariyer fırsatları sunan, ahlaki açıdan olgunlaştıran, bunu mesleğine ve davranışlarına yansıtmasına zemin oluşturan bir sistemin adıdır. Fütüvvetname sahibi yazarlardan Kaşani işle doğrulanmayan her söz beyhudedir sözü ile bu realiteye dikkat çekmektedir (Kazıc1, 2006, s. 70). Bu bakımdan ahilerin, iş başında yapılan eğitimlerle iş dışında yapılan eğitimlerin bütünleşmesini sağladıkları söylenebilir.

Ahilikte süreklilik arz eden eğitimler tasavvufi bir yaklaşımla organize edilmiştir. Tasavvufta yer alan şeyh, halife, mürid ve muhib sınıflandırması Ahilikte usta, kalfa, çırak ve yamak şeklinde düzenlenmiş, eğitimler de buna göre tasavvufi bir anlayışla planlanmış ve uygulanmıştır. Ahi Evran'ın eğitim dokümanı olarak nitelendirilebilecek eserlerini bu anlayışla basitten mürekkebe şeklinde

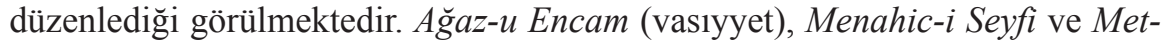
liu-l İman eserleri buna örnektir (Bayram, 1995, s. 48-49).

Ahilik sistemi eğitim/değerler eğitimi bileşenleri (amaç, ihtiyaç belirleme, eğitimci, ortam, içerik, yöntem, kullanılan araç-gereç, sonuçların değerlendirilmesi ve iyileştirmeler) bakımından değerlendirildiğinde (Yeşil ve Kart, 2018, s.166) günün şartlarına göre dikkat çekici bir niteliğe sahip olduğu söylenebilir.

Ahilik eğitim sisteminin insan tabiatına uygun, bireyin kendini tanımasına ve yeteneklerini ortaya çıararak geliştirmesine firsat veren bir yapıya sahip olduğu erdemli, içinde bulunduğu her ortama değer katan, faydalı bireyler yetiştirmeyi amaç edindiği görülmektedir. Hayat felsefesi olarak dünya-ahiret dengesi benimsenmiş, sorumluluk daima ön planda tutulmuştur. Ahilik modelinin temelini güvene dayalı ilişkilerin oluşturduğu anlaşılmaktadır. Ebeveynler hem iyi bir insan, hem de meslek erbabı olarak yetiştirileceği hususunda sisteme güvenleri nedeniyle çocuklarını eti senin kemiği benim anlayışı içinde işyerlerine teslim etmişlerdir.

Ahilikte eğitimlerle sadece mesleki bakımdan gelişimi değil, aynı zamanda davranışsal gelişim ve ahlaki olgunluğu sağlamak hedeflenmiştir. Bu durumu çalışma ilişkileri ve diğer alanlarda açıkça görmek mümkündür. Eğitimlerin katılımcıların yaş grubu, statü, bilgi düzeyi vb. (ihtiyaca göre) farklılaştırıldığ 1 görülmektedir.

Eğitimin etkinliği bakımından ihtiyaç belirleme/eğitim açığının bilinmesi önemlidir. Sağlıklı bir planlama buna bağlıdır. Kişi, görev ve örgütsel analiz 
bu sürçte önemli rol oynar (Noe, 1999, s. 54-58). Ahilikte eğitim ihtiyaçlarını genel (bilgi) ihtiyaçlar, iş ve mesleğin gerektirdiği (mesleki bilgi) hiyerarşik düzeye dayalı ihtiyaçlar olarak iki kategoride değerlendirmek mümkündür. İhtiyaç belirlemede gözlem ve iş gerekleri önemli rol oynamıştır. Fütüvvete layık olabilmek için sanatkarlığın yanında bilgili olmak da şart koşulmuştur. Esnaf ve sanatkarlara gündüz işyerlerinde yamak, çırak, kalfa ve usta hiyerarşisi içinde verilen mesleki eğitimlerle, akşam toplantılarında verilen ahlaki ve terbiyevi eğitimler bu kapsamdadır. Değerler eğitimi ile mesleki eğitimlerin bütünleşik olması sistemin en önemli yönünü oluşturmuştur. Güçlü bir dayanışma ve yardımlaşmaya zemin hazırlayan bu tür uygulama ve örgütlenmelerin sadece şehirlerde değil, kasaba ve köylerde de mevcut olduğu bilinmektedir (Çağatay, 1997, s. 213-214).

Yaygın bir eğitim kurumu (Akyüz, 1985, s. 47) olarak hizmet veren Ahilikte çırakların örgün eğitimden kopmamaları, temel eğitimlerini mektep ve medreselerde almaları zorunlu kılınmıştır II. Mahmud (1808-1839) zamanında çıkarılan bir fermanla çırakların okulda aldıkları İslami değerler eğitimi sertifikası ile çıraklığa kabulü şart koşulmuştur (Tabakoğlu, 1986, s. 417-418).

Eğitimde ortam önemlidir. Eğitim ortamı, eğitilen beceri ve davranışların kullanılmasını arttırıcı veya azaltıcı etkisi olan ve katılımcıların algılarını belirleyici bir niteliğe sahiptir (Noe, 1999, s. 135). Bu nedenle, ahilerin eğitim ortamlarının fiziki ve manevi (örgütsel iklim) bakımdan elverişliliğine büyük önem verdikleri görülmektedir.

Ahilikte mektep ve medreseler dışında eğitim ortamları olarak işyerleri/çarşılar, zaviyeler, camiler ve yaren evlerinin kullanıldığı görülmektedir. Değerler eğitimi hem işyerinde hem de zaviyeler/yaran evlerinde süreklilik arz eden bir şekilde gerçekleştirilmiştir. İşyerlerinin genellikle medreseler yakınında olması meslek eğitimi yanında değerler eğitimi alma firsatı da sağlamıştır. Ahilerin tekke ve zaviyelerin yanında cami, medrese ve kütüphaneler yaptırmaları bu anlayışı ortaya koymaktadır (Tabakoğlu, 2008, s. 250; Kazıcı, 2006, s. 69-71). Çıraklık ve kalfalık döneminde gençlerin ustaları tarafindan uygulamalı değerler eğitimine tabi tutulduğu görülmektedir (Ünsür, 1988, s. 547).

Anadolu'nun neredeyse tamamında örgütlenen Ahi birlikleri oluşturdukları zaviyelerde misyonlarını icra etmişlerdir (Parmaksızoğlu, 1971, s. 9). Zaviyelerin misafirlerin ağırlanması dahil çok fonksiyonlu (multifonctional) yapılar olduğu, Ahilik misyonu hizmetleri için uygun olarak inşa edildiği görülmektedir (Güllülü, 1977, s. 64). Zaviyelerde yürütülen faaliyetlerin başında üyelerin eğitimi ve gelişiminin sağlanması yer almıştır. Genel eğitimlerin yapıldı̆̆g Ahi 
zaviyeleri öncelikle ilgili meslek grubu üyelerine hizmet vermişlerdir. Büyük merkezlerde her meslek grubunun birden fazla zaviyesi olabildiği gibi, küçük yerlerde bütün meslek erbabı tek bir mekânda toplanabilmişlerdir (Ekinci, 2008, s. 78).

Eğitimin etkinliği açısından içeriği, ihtiyaçlara uygunluğu ve katılımcıların öğrenme arzuları önemlidir. Ahilikte ahlak/değerler eğitimin iki temel boyutu bulunduğu ifade edilebilir. Bunlardan birincisi işbaşı, ikincisi ise iş dışı eğitimlerdir. Usta ve kalfalar tarafından sözlü ve uygulamalı olarak verilen işbaşı eğitimlerinde mesleğin incelikleri yanında mesleki değerler ve davranış kurallarının anlatıldığ 1 , sakınılması gereken hususlardan bahsedildiği görülmektedir. İş dışı eğitimlerin ise daha ziyade zaviyelerde ve ev sohbetlerinde verildiği, bu tür eğitimlerin yapıldığı zaviyelerin vakıf sistemi anlayışı ile yönetildiği, buraların ihtiyaçlarının ise çeşitli yerlerde oluşturulan akarlarla karşılandığı ve esnafın da buralara aidat ödediği bilinmektedir (Çağatay, 1997, s. 50; Önge, 1988, s. 531). Zaviyelerde yapılan eğitimlerin temelini ahlak ve adab-1 cemiyetin (davranış kuralları) oluşturduğu (Muallim Cevdet, 1919, s. 77-78), bu eğitimlere her daldan bilginler, muallimler ve hatiplerin katıldığ 1 , buraların beceri ve yeteneklerin gelişimine katkı sağlayan birer akademi fonksiyonu icra ettiği anlaşılmaktadır (Çağatay, 1997, s. 244-246; Ekinci, 2008, s. 61).

Ahilikte her sanat ve meslek kolunun bir piri (ahi baba) bulunduğu, şehir ve kasabalarda oluşturulan örgütler aracılığı ile eğitim amaçlı birtakım organizasyonların düzenlendiği, ahi babanın kendi ahilerini zaviyelerde topladığı, onları Ahilik ilke ve değerleri çerçevesinde sanat, sosyal ve sportif (askeri amaçl1) alanlarda eğitip yetiştirdiği görülmektedir. Sanat eğitimleri hiyerarşik düzeye uygun şekilde işbaşında yapılırken, sosyal ve kültürel eğitimler zaviyelerde belirli günlerde yapılan toplantılarda dini, edebi ve öğütsel kitap okumaları ve sohbetleri dinlemek suretiyle gerçekleştirilmiştir. Genellikle cuma akşamları yapılan ahi sohbetlerinde Kur'an, hadis, menakıb, muamelat-1 hükema, evsaf-1 müzekka, sergüzeşt-i şüheda, nisbet-i ahibba, letaif-i zürefa, esrar-1 fikara, süluk-u so vefa, belağat-1 şuera okunduğu bilinmektedir (TESK, 1973, s. 29).

Köylerde ise gençlerin eğitimi için akşamları yaran odalarının kullanıldığı, birtakım oyunların da oynandığı bu odaların yaşlılar bölümünde Muhammediye, Ahmediye, Siyer-i Nebi, Battalgazi gibi eserlerin okunduğu (Çağatay, 1994, s. 112-148), yaran sohbetlerinin çoğunluğunu gençlerin oluşturduğu 20-25 kişilik gruplarla gerçekleştirildiği görülmektedir (Ekinci, 2008, s. 147). 
Ahi zaviyelerinin aynı zamanda birer halk eğitim merkezleri olarak da hizmet verdiği anlaşılmaktadır. Zaviyelerde okuma-yazma eğitimleri yanında Kur'an-1 Kerim, edebiyat, Türkçe ve Arapça dilbilgisi, güzel yazı ve musiki dersleri de verilmiştir. Divan edebiyatı şairi Baki (1526-1600)'nin de bir saraç çırağı olarak bu eğitimlerden geçtiği ifade edilmektedir (Ekinci, 2008, s. 78).

Ahi zaviyelerinde üyelerin bilgi ve kültür düzeylerini geliştirmek için yedi ya da dokuz basamaklı bir hiyerarşi oluşturulmuştur. En üst makam 'ahi baba'lıktır. Zaviyelerde toplanan esnaf ve sanatkârlar adab-1 muaşeret (görgü kuralları), vatandaşlık, askerlik gibi genel konularda eğitilmiştir. Ahi baba başkanlığında haftanın belirli günlerinde Kur'an-1 Kerim, Siyer-i Nebi, İlmihal, Kısas-1 Enbiya gibi eserlerin okunması ve fütüvvetnamelerde yer alan ilke ve değerlerin öğretimi amacıyla toplanılmış, buralarda yapılan akşam toplantılarına ise her daldan ilim adamları, vali, kadı, müderris, yönetici, tabip, komutan vb. üst düzey katılım gerçekleşmiştir. Bu katılımcıların çoğu zaviye, medrese, han, hamam yaptırmış, buraların bakımı için ise vakıflar kurmuşlardır (TESK, 1973, s. 31).

Eğitimcinin yetkinliği eğitimin etkinliği açısından son derece önemlidir. Gerek zaviyelerde, gerekse işyerlerinde konusuna hakim kişilerin bu konuda rol aldığ görülmektedir. Zaviyelerde ders verenlere muallim ahi ve emir denilmiş, buralarda şehrin kadısı ve müderrisler de ders vermişlerdir (Köprülü, 1981, s. 402). Zaviyelerde verilen dersler daha sıcak atmosferde gerçekleştirildiğinden medreselere göre daha etkili olduğu anlaşılmaktadır. Eğitimlerin seviyelerinin kariyer süreçleri ile de ilişkilendirildiği görülmektedir (Ünsür, 2018, s. 417-418).

Ahilikte sistemin eğitim firsatlarından yararlanabilmek için ustanın çırağ hakkında şahitlik etmesi, güvence vermesi ön şart olarak belirlenmiştir. Çıraklar mesleki eğitimlerini ustasından aldıklarından bunlar psikolojik, edebi ve içtimai eğitimlere tabi tutulmuşlardır. Bu eğitimlerde görev alan eğitimcilere muallim ahi ya da pir adı verilmiştir. Kur'an tilaveti, fütüvvetname, adap, tarih, tasavvuf, edebiyat, musiki vb. eğitim konuları arasında yer almıştır. Bu eğitimlerde akli ilimlerden ziyade mefkure-i insaniye telkinine yarayan araçlar kullanıldığ görülmektedir (Muallim Cevdet, 1919, s. 140-141). Ahilikte, sistemin tabii işleyişinde eğitici rolü üstlenmelerin dışında ayrıca profesyonel eğitimciler de kullanılmıştır. Mevlana'nın oğlu Ahi Çelebi bunlardandır (Bayram, 1995, s. 56).

Eğitimde eğitimcinin yetkinliği, ortam ve içerik yanında kullanılan yöntem ve teknikler ile materyal de oldukça önemlidir. Ahilikte terfi törenleri de eğitim ortamı olarak kullanılmıştır. Terfi edebilmek için sadece mesleki yeterlilik kafi görülmemiş, dürüstlük, haram-helale dikkat etmek, müşteriyi aldatmamak gibi 
ahlaki erdemler de aranmıştır (Sevinç, 1992, s. 103). Terfiler törenlerle gerçekleştirilmiş, bu suretle kişinin onurlandırılması amaçlanmıştır. Terfi törenlerinde genel ve mesleki ahlak değerleri ile bunlara uymanın öneminin hatırlatılması ve birtakım öğütlerde bulunulması (Çağatay, 1997, s. 137-139) eğitsel fonksiyonunu ortaya koymaktadır. Bu tür törenlerin nasihat (öğüt) yöntemi kullanılarak gerçekleştirilen birer eğitim ortamı niteliğinde olduğu anlaşılmaktadır. Bu törenlere müftü, kadı ve üstad gibi zevat da katılmış, katılımcılara ayet ve hadisler 1şığında değerler eğitimi niteliğinde nasihatlarda bulunmuşlardır (Ergin, 1922, C.1., s. 692-711). Ayrıca esnaf şeyhi ve ustaların da söz alarak motive edici, eğitici ve uyarıcı nasihatlarda bulunduğu görülmektedir.

Sohbetle eğitim Ahilikte kullanılan en önemli yöntemlerdendir. Fütüvvet gereklerinden biri de güzel sohbet etmek ve sohbet edebini güzelce yerine getirmektir. Kaşani (ö.1329) Fütüvvetnamesinde sohbet ile ilgili şöyle demektedir; bu yola giren sohbetle faziletleri kazanir, onların adetlerini adet edinir ve bunu meleke haline kor. Çünkü önde gidene uymaktan ve sohbetten fazla nefse tesir eden yoldaştan başka ruh açan hiçbir şey yoktur (Gölpınarlı, 1949-1950, s. 290-291). Sülemi ise sohbet adabı ile ilgili şunları ifade etmektedir; Sohbetin edebi kendinden üstün olana hürmetle, kendine denk olana muvafakat ve ülfetle, kendinden aşağı olana şefkat ve merhametle, ana-babaya tevazu ve itaatle, çocuklara merhamet ve güzel terbiye ile kadına idare ile akrabalara iyilik ve ziyaret etmekle, ihvana doğru sevgi ve sevgiye engel halleri savmakla, komşulara eziyetten el çekmekle, bütün insanlara güleç yüzlülük ve el açıklğg ile fakirlere (sufilere) haklarına hürmet ve kadirlerini bilmekle, zenginlere ihtiyaç göstermemekle, bilginlere işaret ettikleri şeyleri kabul etmekle, evliyaya boyun büküp itaat etmek ve inkârı bırakmakla, sohbet etmek bid'atçılar, iddiacılar, insanları kendilerine tabi knlmak ve onların ellerindekini almak için zühd gösterenlerden kaçmakla olur (Sülemi, 1977, s. 60-61).

Ahilikte eğitimlerin bilgilendirme fonksiyonu yanında eğlendirici ve dinlendirici yönü de ihmal edilmemiştir. Akşamları zaviyelerde ve yaran odalarında yapılan etkinlikler bu türdendir. Ahilerin özellikle kışın Anadolu'da helva sohbetleri yaptığı, helvanın yapımı ve yenmesi esnasında Hz. Muhammed (SAV)'in hayatı ve ona bağl1lıkla ilgili metinler okudukları görülmektedir (Faroqhi, 2011, s. 70).

Ahiler yılın belirli günlerinde günümüzde bazı işyerleri tarafından düzenlenen açık alan etkinliklerine(outdoor) benzer etkinlikler de düzenlemişlerdir. Ziyafet ve üç günler toplantıları bunlardandır (TESK, 1973, s. 61-64). Yeme, içme, sohbet ve eğlence aksiyonlu bu toplantılarla yeni bir şeyler öğrenmek, 
kaynaşmak ve daha zinde bir şekilde işe hazırlanmak amaçlanmıştır. Ziraatla uğraşan ahilerin ise harman sonunda uygun bir ortamda toplanıp sohbet ederek eğlendikleri ve kaynaştıkları bilinmektedir

Temel prensiplerini İslam'dan alan Ahilikte Hz. Muhammed (SAV)'in eğitimde kullandığı yöntemlere benzer yöntemlerin kullanıldığı görülmektedir. Dikkat çekici ifadelerle söze başlama, konuya uygun üslup ve ifadeleri tercih etme, tedriç, kıssalardan yararlanma (vak'a), benzetme (teşbih) ve karşılaştırma (mukayese), örnek alma (rol-model), isticvap, tekrar vb. bunlardandır (Kandemir, 1979, s. 373-400; Kaya, 2013, s. 47-49; Ryan, 1991, s. 99-105). Ahilik sisteminde günümüz eğitiminde uygulanan aktif öğrenme, öğrenci merkezlilik, okul dış1 eğitimi gibi yöntemlerin kullanıldığı görülmektedir.

Ahilikte pir, yol, ata, yol kardeşi tutma, belirli sürelerde mesleğin belirli kademelerinden geçme yolu (yöntem) ile gençlere sanat becerisi, ahlak ve terbiye öğretimi, ustalık derecesine ulaşılıp dükkan sahibi olunduğunda kazanılan paranın hilesiz hud'asız alın teriyle ve helalinden olması gerektiği benimsetilmesi hedeflenmiştir. Sanatkarın her şeyden önce sanatının pirinin (rol model) bir peygamber veya ulu bir kişi olduğu inancına sahip olması gerektiği vurgulanmıştır (Çağatay, 1997, s. 157). Özdenetimin ön plana çıktığı sistemin kendini kontrol eden mekanizmalara da sahip olduğu bilinmektedir (Ünsür, 1998, 550).

Tarihe mal olmuş Ahilik sisteminin ortaya koyduğu eğitim modeli değerler eğitimi açısından Batı kaynaklı yöntemlere alternatif olarak sunulabilecek en güçlü yapılardan birisi olarak değerlendirilebilir (Yeşil ve Kart, 2018, s.163). Ahiliğin bünyesinde barındırdığı değerler sayesinde hem Selçuklu hem de Osmanlı döneminde toplumun en önemli dinamiklerinden biri olduğu, iktisadi ve sosyal hayatın güçlenmesine, iç ve dış her türlü riskler karşısında direnç kazanılmasına zemin oluşturduğu anlaşılmaktadır.

\section{Ahilik Sisteminin Çöküşü}

16. yüzyılın sonlarına doğru Ahi birliklerinde çözülmelerin başladığı görülmektedir. Bunun başlıca nedenleri olarak ticaret yolları ve iktisadi alanlardaki değişikliklerle devletin bu alandaki müdahaleci politikaları gibi dışsal faktörler gösterilmiş olsa da içsel faktörlerin dinamizmini koruduğu hiçbir yapının sadece dışsal faktörlerle yıkılamayacağını da göz ardı etmemek gerekir. Bu süreçte, kardeşliği esas alan dayanışmacılığın yerini iktisadi menfaatlere dayalı işbirlikçiliğin almaya başladığ dikkati çekmektedir (Türkdoğan, 1981, s. 671). 
Ahiliği ayakta tutan değerlerden uzaklaşılmaya başlanmasıyla birlikte (bu aynı zamanda değerler eğitimi sürecinin zayıflamasını da ifade etmektedir) bu dinamik yapının çözülmeye başladığı görülmektedir. Loncalaşma süreci olarak da ifade edilebilecek olan bu durumu Yahya b. Halil Fütüvvetnamesinde şu şekilde ifade etmektedir; Şöyle gördüm ki fütüvvet ehli şaşkın halde olup batılla meşgul oldular. Hidayeti koyup bid'ata uğradılar, Şehvetleri galip olup bunlara hâkim oldu. Çok mal dizdiler, ma'rifet yerine kavga ve çekişler koydular, gökten inen sofraya haram taam koydular, miskinlik yerine benlik koydular, kemliği ve yavuz ise varmayl fütüvvet yerine koydular, taat yerine fesat koydular (Ülgener, 2006, s. 147-148).

Ahilik sisteminin loncalar haline dönüşmesi 17. yüzyıl ortalarına rastlamaktadır. Evliya Çelebi'nin ifadesine göre bu dönemde 1109 lonca teşkilatı bulunmakta idi. Çözülme sonucu loncalaşan Ahi birlikleri de 1727 tarihinden itibaren gedikler haline dönüşmüş (Ekinci, 1989, s. 55; TESK, 1973, s. 49), 17 Haziran 1861 tarihinde merkezi yönetim kararı ile gedik usulü de ortadan kaldırılmıştır. 1912 yılında çıkarılan bir kanunla da loncaların faaliyeti tamamen sonlandırılmıştır (Ekinci, 1989, s. 55-56; TESK, 1973, s. 49-125).

Ahilik sisteminde çeşitli nedenlerle baş gösteren yozlaşmalara rağmen yüzlerce yıllık ahlaki değerlere dayalı yapının tamamıyla bozulduğunu iddia etmek güçtür. Nitekim 18. ve 19. yüzyıl seyyahlarının Osmanlı coğrafyasından elde ettikleri izlenimler eserlerine bu doğrultuda yansımıştır. Örneğin, 18. yüzyıl Osmanlı Türkiye'sini araştıran D'ohsson şöyle demektedir; Müslümanların ana hedefi sanayiyi teşvik etmek, insanları çalışmaya sevk etmek, onların iyiliksever beşeri duygularla mücehhez olmalarını sağlamak, fazilet duygusunu ve tevazu zevkini aşılamak, kötülügün çamuruna düşmelerini önlemek, her türlü israftan alıkoymak ve her türlü medeni mesleği değerlendirmektir (D'ohsson, ty, s. 129). Günümüzde Ahiliğin iktisadi ve sosyal alanlardaki izlerine özellikle Anadolu'da sıç̧a rastlamak mümkündür.

\section{Sonuç ve Öneriler}

Temeli ahlaki değerlere dayalı eğitim ve yönetim anlayışı olarak ifade edebileceğimiz Ahilik örgüt modelini günümüz ifadesiyle öğrenen organizasyon (learning organization) olarak nitelendirmek mümkündür. Öğrenen organizasyon; öğrenme, uyum ve değişim kapasitesini yükseltmiş örgütsel yapıdır. Öğrenen organizasyonlarda sürekli öğrenme, bilgiyi paylaşma, fikir üretme, bilginin ödüllendirilmesi terfi vb. ile cesaretlendirme ve kişiye değer verilmesi ana özel- 
liklerdir (Mondy, 2017, s. 166; Noe, 1999, s. 142-143). Öğrenen organizasyonların ana malzemesi ahlaki değerler olduğunda, yaşanması muhtemel sorunlarla karşılaşma riskleri önemli ölçüde azalmaktadır (DeCenzo vd, 2017, s. 20). Bu özelliği, Ahiliğe asırlarca koruyucu kalkan vazifesi görmüştür.

Değerler eğitimini merkeze alan Ahilik sisteminin eğitim politikası ve yaklaşımlarını şu şekilde özetlemek mümkündür;

- Kendisi ile barışık, dürüst, bilgi ve beceri sahibi, sürekli öğrenen ve gelişen, paylaşımc1, içinde bulunduğu topluma fayda sağlayan ahlaklı bireyler yetiştirmek ana politika olarak belirlenmiştir.

- İnsan bir bütün olarak ele alınmış mesleki, ahlaki ve içtimai bilgiler bu bütünlük içerisinde verilmiştir.

- Eğitim en önemli yatırım olarak görülmüş (araştırmalar ABD'de bile işverenlerin çalışanlarının sadece \%16'sına eğitim imkânı sunabildiklerini göstermektedir, Noe, 1999, s. 8-9), maliyetler (devlete herhangi bir ekonomik yük getirmeksizin) teşkilat tarafından karşılanmıştır.

- Eğitim, yaşam boyu devamlılık arz eden bir süreç olarak görülmüş̧ür

- İş başı ve iş dış1 eğitimler bütünlük içinde, birbirini tamamlayıcı şekilde tasarlanmış ve uygulanmıştır.

- Eğitim örgütlenmesi bütün yerleşim birimlerini kapsayacak şekilde gerçekleştirilmiştir.

- Eğitim ortamları Ahilik değerlerini benimsemiş herkese açık tutulmuştur.

- Eğitimler gerekli şartları taşıyan herkese ücretsiz olarak sunulmuştur.

- Eğitim konuları mesleki bilgilerle birlikte ahlaki değerleri ve bu konuda örnek kişilerin hayat hikayelerini kapsamaktadır.

- Eğitimciler, konusunda uzman kişilerden oluşturulmuştur (Ahi şeyhleri yanında kadılar ve müderrisler de eğitim sürecine katkı sağlamışlardır).

- Eğitim ortamları (işyeri-iş dışı) fiziki ve manevi açıdan en uygun şekilde hazırlanmıştır.

- Eğitimlerde konuya ve katılımcıların durumuna göre en uygun yöntemler tercih edilmiştir (anlatım, vaka, uygulama, davranış modelleme, soru-cevap vb.).

- Eğitimlerde başta fütüvvetnameler olmak üzere, değerler eğitimi ve mesleki eğitimle ilgili en uygun materyaller kullanılmıştır (Kur'an-1 Kerim, hadis-i şerifler, peygamberler ve diğer örnek şahsiyetlerin hayatı vb.).

- Eğitim sonuçlarının beklenen davranışlara dönüşmesi ve mesleki başarıya katkısı başta ustalar olmak üzere ilgililer tarafindan sürekli izlenmiş (etkinlik değerlendirmesi), pedagojik çerçevede gerektiğinde düzeltici yaklaşımlar ortaya konulmuştur. 
- Eğitimlerin performansa yansımasına firsat verilmiş, kariyer yolları açık tutulmuş, herhangi bir kıskançlık oluşmaksızın kişiler bu konuda desteklenmiştir.

Yukarıda yer alan hususlar değerlendirildiğinde günümüz modern eğitim sisteminde de benzeri yaklaşımların benimsendiğini söylemek mümkündür. Ancak, sağlıklı sonuçlar alabilmek için sistemin iyi kurgulanması yanında kararlılıkla uygulanması da gerekmektedir. Örneğin; Milli Eğitim Temel Kanunu'nda da vurgulanan 'ahlaki, insani, manevi ve kültürel değerleri benimseyen, dengeli, bilgili, karakterli ve sorumluk sahibi (erdemli) bireyler yetiştirme' amacina ulaşmada henüz beklenen düzeye gelinemediği görülmektedir. Bunun başlıca nedeni olarak ana politikada tanımlanan hususların başta politik etkenler olmak üzere birtakım nedenlerle yeterince uygulanamaması ve sürece sıkça yapılan müdahaleler gösterilebilir. Din ve ahlak eğitimi ile ilgili olarak yaşanan süreç de bunun önemli bir göstergesi durumundadır. 1983 yılında Din Eğitimi Genel Müdürlüğü'nün adının Din Öğretimi Genel Müdürlüğü olarak değiştirilmesi bile, eğitim-öğretim bütünlüğü açısından değerlendirildiğinde, bu alanda yapılan müdahalelere dikkat çekici örneklerden biri olarak değerlendirilebilir. Ahiliği bu konuda başarılı kılan bütünleşik bir eğitim politikası ile kamu müdahalesine maruz kalmaksızın, hatta bazen kamu desteğini de arkasına alarak politikalarını gereğince ve kararlılıkla uygulayabilmesi olarak görülmektedir.

Günümüz eğitim sistemi açısından değerlendirildiğinde Ahilik’ten alınabilecek pek çok örnekler bulunmaktadır. Bunların başında genel eğitim (örgün/ yaygın) ve mesleki eğitim programlarının değerlerle bütünleşik hale dönüştürülmesi, planlama ve uygulamanın da buna uygun hale getirilmesi gelmektedir. Değerler eğitimi okul öncesinden (ana sınıfi) başlayarak sürecin bütününü kapsamalı, eğitimcilerin tamamı bu konuda yetkin hale getirilmeli, sadece eğitim kurumları değil aileler, sivil toplum kuruluşları ve toplumun bütün kesimleri sürecin bir parçası haline dönüştürülmeli ve katılımları sağlanmalıdır. Ancak bu suretle öğrenen, paylaşan, dayanışmayı vazife bilen birey, örgüt ve toplum haline dönüşmek mümkün olabilecektir. Ahlaki değerlerin göz ardı edilmesi sonucu ortaya çıkan günümüz sorunlarını aşabilmenin, değerleri hayatın her safhası ile ilişkilendirmekle (eğitimli ve erdemli bireyler yetiştirmek) mümkün olabileceği unutulmamalıdır. 


\section{Kaynakça}

Acluni, İ. M. (1985). Keşf-ul hafa (C. 1-2). (Neşr. A. el Kalaş). Beyrut.

Ahmed Rif'at (1881). Lügat-l tarihiyye ve coğrafiye (C.1-7). İstanbul: Mahmud Bey Matbaas1.

Akao, Y. (1999). Hoshin kanri yönetim pusulası (T. Sancı Çev.). İstanbul: MESS Yayınlar1.

Akyüz, Y. (1985). Türk e ğitim tarihi. Ankara: Ankara Üniversitesi Eğitim Bilimleri Fakültesi Yayınları.

Andrews, K. R. (2005). Uygulamada ahlak, şirket ahlakı (C. Engin Çev.). İstanbul: MESS Yayınları.

Araz, N., Günay, U., Tan, N., Toygar, K., Öksüz, E. \& Seyidoğlu, B. (1994). 21. Yüzyılın eşiğinde örf ve adetlerimiz. İstanbul: Boğaziçi Yayınları.

Argüden, Y. (2004). Geleceği şekillendirmek. Rota Yayıncılık.

Arslan, M. \& Berkman, A. Ü. (2009). Dünya'da ve Türkiye'de iş etiği ve etik yönetimi. İstanbul: TÜSİAD Yayınları.

Aydın, İ. P. (2003). Eğitim ve öğretimde etik. I. Ulusal Etik Kongresi Bildiriler Kitabl içinde (ss. 138-141). Erişim adresi: http://www.phil.metu.edu.tr/ etik-1kongre-kitap.pdf

Baltaş, A. (2009). Işse ve insana değer katan yeni İK. İstanbul: Remzi Kitabevi.

Barutçugil, İ. (2004). Stratejik insan kaynaklarl yönetimi. İstanbul: Kariyer Yayıncilık.

Bayram, M. (1981). Anadolu Selçuklularından günümüze din eğitimi Türkiye 1. din eğitimi semineri. Ankara: İlahiyat Vakfı Yayınları.

Bayram, M. (1995). Ahi Evren tasavvufi düşüncenin esasları. Ankara: TDV Yayınları.

Bell, D. (1978). The cultural conradictions of capitalism. New York: Basic Books.

Berkowitz, M. W. (2011). What works in value educations. International Journal of Educational Research. 50, 150-153.

Bertrand, A. (2001). Ahlak felsefesi. İstanbul: Akçağ Basım Yayım Pazarlama Aş.

Bilgin, N. (1995). Sosyal psikolojide yöntem ve pratik çalışmalar. İstanbul: Sistem Yayıncilik.

Blanchard, K. \& O'connor, M. (1998). Değerlerle yönetim. İstanbul: Epsilon Yayıncılık

Bowen, H. R. (1953). Social responsibilities of businessman. New York: Harper.

Boyatzis, R. E. (2005). Daha iyi bir kültür yaratmak etik zekâ (Ş. Alpagut, E. ve H. Nal Çev.). İstanbul: CSA Global Publishing.

Buhari, M. İ. (1315). El-Camiu's-sahih (C. 1-8). 
Covey, S. R. (2008). Etkili insanların 7 alışkanlığ (O. ve F. N. Deniztekin Çev.). İstanbul: Varlık Yayınları.

Cramer, S. F. \& Browne, G. S. (1977). Çă̆daş ĕgitim (A. F. Oğuzkan Çev.). İstanbul: MEB Yayınları.

Çağatay, N. (1994). Güncel konular üzerine makaleler. Ankara: Türk Tarih Kurumu Yayınları.

Çağatay, N. (1997). Bir Türk kurumu olan ahilik. Ankara: Türk Tarih Kurumu Yayınları.

Çağlayan, A. (2005). Ahlak pusulası (Ahlak ve değerler ĕgitimi). İstanbul: DEM Yayınları.

Çağrıcı, M. (2013). Gazzali'ye göre Íslam ahlakı. İstanbul: Ensar Neşriyat.

Çamdibi, H. M. (1983). Şahsiyet terbiyesi ve Gazali. İstanbul: Han Neşriyat.

DeCenzo, D. A., Robbins, S. P. \& Verhulst, S. L. (2017). Insan kaynakları yönetiminin temelleri (C. Çetin ve M. L. Arslan Çev. Ed.). Ankara: Nobel Akademik Yayıncilik.

Delgrosso, S. (2004). Core values of project management. Member Forum. Erişim adresi: http//www.iienet.org

Demir, Ö. (2002). Piyasa ekonomisi ve ahlak. Piyasa, 1(3), 3-13.

Doğan, B., Aşkun, O. B. ve Yozgat, U. (2007). Türkiye'de yönetsel değerler ve yönetici profili üzerine bir araştırma. İstanbul: Beta Basım.

D’ohsson M. (ty). 18. Yüzyll Türkiye’sinde örf ve adetler (Z. Yüksel Çev.). Tercüman 1001 Temel Eser: 3.

Dose, J. J. \& Klimoski, R. J. (1999). The diversity of diversity: Work values effect on formative team processes. Human Resource Management Review, 9(1), 83-108.

Durkheim, E. (1986). Meslek ahlakı (La morale professionnelle). İstanbul: Milli Eğitim Basımevi.

Ekinci, Y. (1989). Ahilik ve meslek ĕgitimi. İstanbul: MEB Yayınları.

Ekinci, Y. (2008). Ahilik. Ankara: Özgün Matbaacılık.

Ennulo, J. \& Turnpuu, L. (2001). An intercultural comparison of management values among business school students and teachers. TRAMES, 5(4), 336-344.

Eren, E. (2010). Örgütsel davranış ve yönetim psikolojisi. İstanbul: Beta Basım.

Eren, E. (2011). Yönetim ve organizasyon. İstanbul: Beta Basım.

Ergin, O. N. (1922). Mecelle-i umur-u belediye (C.1-5). İstanbul: Matbaa-i Osmaniye.

Es-Sadr, M. B. (1980). İslam ekonomi doktrini. İstanbul: Hicret Yayınları.

Evliya Çelebi, (1898-1902). Seyahatname (C. 1-8). İstanbul: İkdam Matbaası.

Faroqhi, S. (2011). Osmanlı zanaatkârları (Z. Kılıç Çev.). İstanbul: Kitap Yayınevi. 
Gölpınarlı, A. (1949-1950). İslam ve Türk illerinde fütüvvet teşkilatı ve kaynakları, Ístanbul Üniversitesi İktisat Fakültesi Mecmuast, 11, 1-4.

Gregoire, F. (1971). Büyük ahlak doktrinleri (C. Süreyya Çev.). İstanbul: Varlık Yayınevi.

Greinert, W.D. (1996). İkili mesleki eğitim sisteminde gerekli yapısal önlemler. 2000 Yılında Mesleki Eğitim Sempozyumu (16 Ekim 1996) Bildiriler Kitabı içinde (ss. 6-13). İstanbul: TOBB-TAMEM Yayını.

Gülerman, A. ve Taştekil, S. (1993). Ahi teşkilatının Türk toplumunun sosyal ve ekonomik yapısı üzerindeki etkileri. Ankara: Kültür Bakanlığı Yayınları.

Güllülü, S. (1977). Ahi birlikleri. İstanbul: Ötüken Yayınları.

Güney, S. (2015). Sosyal psikoloji. Ankara: Nobel Akademik Yayıncılık

Güngör, E. (1993). Değerler psikolojisi üzerinde araştırmalar. Ötüken Neşriyat, İstanbul.

Güvenç, B., Oktan, P., Belek, T., Akarsu, F., Tözeren, S. \& Özden, M. A. (1998). Japon eğitimi. İstanbul: MEB Yayınları.

Hamel, G. ve Breen, B. (2007). Yönetimin geleceği (F. Gülfidan Çev.). İstanbul: MESS Yayınları.

Hamitoğulları, B. (1986). İktisadi kalkınmamızda ahiliğin anlamı ve önemi, ahilik ve esnaf. İstanbul: İstanbul Esnaf ve Sanatkârlar Dernekleri Birliği Yayınları.

Hamitoğulları, B. (1987). İktisadi vahşi büyümenin bunalımları ve İslam kalkınma modelinin vaat ettikleri, iktisadi kalkınma ve İslam. İstanbul; İslami İlimler Araştırma Vakfı (ISAV) Yayınları.

Hazlitt, H. (2002). Kapitalizmin etiği (N. Kandemir Çev.). Piyasa 1(3), 15-34.

Herriot, P. (1976). Essential psychology: Values, attitudes and behavior change. New York: Methuen Co. Ltd.

Hökelekli, H. \& Gündüz, G. (2007). Üstün yetenekli çocukların değer yönelimleri ve eğitimleri. Değerler ve Eğitimi Uluslararası Sempozyumu (26-28 Kasım 2004) Bildiriler Kitabı içinde (s. 371-396). İstanbul: DEM Yayınları.

Kandemir, Y. (1979). Örneklerle Íslam ahlakı. İstanbul: Nesil Yayınları.

Kaya, U. (2013). Değerler eğitiminde bir meslek teşkilatı: Ahilik. Dĕgerler Ĕgitimi Dergisi, 11(26), 41-69.

Kaymakcan, R. \& Meydan H. (2014). Ahlak değerler ve eğitimi. İstanbul: DEM Yayınlar1.

Kazıc1, Z. (1988). Ahilik. TDV Íslam Ansiklopedisi, 1, 540-542.

Kazıcı, Z. (2006). Ahilik ve yetişkinlik dönemin eğitimindeki yeri. Yetişkinlik Dönemi Eğitimi ve Problemleri (M. F. Bayraktar Ed.). İstanbul: Ensar Neşriyat. 57-76.

Kelly, J. M. (1987). Building cost effective-training programs. Modern business reports by Alexander Hamilton Institute. New York. 
Kerschenstainer, G. (1977). Karakter kavramı ve terbiyesi (H. F. Kanad Çev.). Ankara: MEB Basımevi.

Kilby, R. W. (1993). The study of human values, University Press of America. Inc. Lanham.

Klause, D. (1996). Mesleki eğitim çerçevesinde meslek kuruluşlarının görevleri ve sorumlulukları. 2000 Yılında Mesleki Eğitim Sempozyumu (16 Ekim 1996) Bildiriler Kitabı içinde (s. 13-18). İstanbul: TOBB-TAMEM

Kluckhohn, C. (1951). Values and value orientations in the theory of action, toward a general theory of action. (T. Parsons ve E. A. Shills Ed.). Harvard University Press, 388-433.

Köprülü, M. F. (1981). Türk edebiyatında ilk mutasavvıflar. Ankara: DİB Yayınları. Köylü, M. (2006). Küresel ahlak eğitimi. İstanbul: DEM Yayınları.

Kuçuradi, I. (2003a). Açılış konuşması, I. Ulusal etik kongresi, 15-20. Erişim adresi: http://www.phil.metu.edu.tr/etik-1 kongre-kitap.pdf.

Kuçuradi, I. (2003b). Etik ve etikler. Türkiye Mühendislik Haberleri, 423, 7-9.

Kuşeyri, A. (1966). Risale, Kahire: A. Mahmud-M. b. Şerif (Neşr.).

Kütükoğlu, M. S. (1986). Osmanlı esnafında oto-kontrol müessesesi, Ahilik ve esnaf. İstanbul: Yaylac1k Matbaas1, 55-77.

Lennick, D. \& Kiel, F. (2005). Etik zekâ (Ş. Alpagut-E. ve H. Nal Çev.). İstanbul: CSA Global Publishing.

Lewis, R. (1973). Osmanlı Türkiye ’sinde gündelik hayat (M. Poroy Çev.), İstanbul: Doğan Kardeş Yayınları.

Mannan, M. A. (1989). İslam ekonomi toplumunun kuruluşu (A. Saidoğlu Çev.). İstanbul: Fikir Yayınları.

Mac Millan (1988). Contemporary Dictionary (W. D. Halsey Haz.). İstanbul: Abc Yayınevi.

McCrae, R. R. (2004). Human nature and culture: Atrait perspective. Journal of Research in Personality. 3-14.

Milli Eğitim Temel Kanunu (1973, 24 Haziran). Resmi Gazete (Say1: 14574).

Mondy, R. W. (2017), Insan kaynakları yönetimi (G. Tozkoparan ve M. Çolak Çev.). Ankara: Nobel Akademik Yayıncılık.

Muallim Cevdet (1919). Tarihi sahifeler: İslam-Türk teşkilat-1 medeniyetinden ahiler müessesesi. Büyük Местиа, No: 5 (Nisan-Haziran).

Noe, R.A. (1999). İnsan kaynaklarının eğitim ve gelişimi (C. Çetin Çev.). İstanbul: Beta Basım Yayım Dağıtım Aş.

Ocak, A. Y. (1996). Fütüvvet. TDV İslam Ansiklopedisi (C. 13), 261-263. 
Önge, Y. (1988). Ahi Evran zaviyesi. TDV Íslam Ansiklopedisi (C. 1), 530-531.

Özen, Ş. (1996). Bürokratik kültür 1: Yönetsel değerlerin toplumsal temelleri. Ankara: TODAİE Yayınları.

Özensel, E. (2003). Sosyolojik bir olgu olarak değer. Değgerler Ĕgitimi Dergisi, 1(3), 217-239.

Parmaksızoğlu, İ. (1971). İbn-i Battuta seyahatnamesinden seçmeler. İstanbul: MEB Yayınları.

Pazarl1, O. (1972). Íslam'da ahlak. İstanbul: Remzi Kitabevi.

Pekolcay, N. (1986), İslami Türk edebiyatı metinlerinde ahiliğin anlam ve önemi. Türk Kültürü ve Ahilik, İstanbul: Ahilik Araştırma ve Kültür Vakfı Yayınları.

Porter, M. E. \& Kramer, M. R. (2005). Kurumsal rekabetin sağladığı rekabet avantajı. Şirketlerin sosyal sorumluluğu (M. Çetinbakış Çev.). İstanbul: MESS Yayınları.

Poyraz, H. (2007). Değerlerin kuruluşu ve yapısı. Değerler ve Eğitimi Uluslararası Sempozyumu (26-28 Kasım 2004) Bildiriler Kitabı içinde (s. 81-88). İstanbul: DEM Yayınları.

Rokeach, M. (1973). The Nature of Human Values. New York: The Free Pres.

Ryan, J. J. (1991). Öğrenmenin oluşumu, Eğitim Psikolojisi (S. Akdeniz Çev.). İstanbul: Marmara Üniversitesi İlahiyat Fakültesi Vakfı Yayınları.

Sabuncuoğlu, Z. (2011). Insan kaynakları yönetimi. İstanbul: Beta Basım.

Sabuncuoğlu, Z. \& Tüz, M. (2001). Örgütsel Psikoloji. Bursa: Ezgi Kitabevi.

Schwartz, S. H. (1994). Are there universal aspects in the structure and contents of human values?. The Journal of Social Issues. 50(4), 19-45.

Sevinç, N. (1992). Osmanlı'nın yükselişi ve çöküşü. İstanbul: Burak Yayınevi.

Soykut, R. (1980). Insanlık bilimi ahilik. Ankara: Afsaroğlu Matbaası.

Sülemi, H. (1977). Tasavvufta fütüvvet (S. Ateş Çev.). Ankara: Ankara Üniversitesi İlahiyat Fakültesi Yayınları.

Şimşek, M. (2000). Toplam kalite yönetimi ve ahilik. İstanbul: Ahi Yönetim Danışmanlık ve Basım.

Şişman, M. (2002). Örgütler ve kültürler. Ankara: Pegem A Yayıncılık.

Ştefanescu, D. C. \& Doval, E. (2010). Implications of ethical values on management. Review of general management, 11, 36-41.

Tabakoğlu, A. (1986). Türk iktisat tarihi. İstanbul: Dergah Yayınları.

Tabakoğlu, A. (2008). Ahilik ve iş ahlakı. İş Ahlakı Sempozyumu Bildiriler Kitabı içinde (s. 37-52). İstanbul: İGİAD Yayınları.

TDK (t.y.). Güncel Türkçe sözlük. Erişim adresi: https://sozluk.gov.tr/

Triandis, H. C. \& Suh, E. M. (2002). Cultural influences on personality. Annual Review of Psychology. 53, 133-160.

Tuna, O. ve Yalçıntaş, N. (1997). Sosyal siyaset. İstanbul: Filiz Kitabevi.

Türkdoğan, O. (1981), Türkiye’nin sanayileşmesi. Ankara: Töre Devlet Yayınevi.

Türkeri, M. (2011). Etik bilinç. Ankara: Lotus Yayınları. 
Türkeri, M. (2015). Etik açıdan değer nasıl oluşur ve pratiğe nasıl yansır?. Değerler ve Eğitimi II Sempozyumu (2012) Bildiriler Kitabı içinde (ss. 401-417). İstanbul: DEM Yayınları.

Türkiye Esnaf ve Sanatkârları Konfederasyonu-TESK (1973). Cumhuriyeti ellinci yılında esnaf ve sanatkâr. Ankara: Güneş Matbaacılık.

Uludağ, S. (1996). Fütüvvet, TDV İslam Ansiklopedisi (C. 13), 259-261.

Ülgener, S. F. (2006). İktisadi çözülmenin ahlak ve zihniyet dünyası, İstanbul: Derin Yayınları.

Ülken, H. Z. (2001). Ahlak. İstanbul: Ülken Yayınları.

Ülken, H. Z. (2013). Eğitim felsefesi. İstanbul: Doğu Batı Yayınları.

Ünsür, A. (1988). Geleneksel Türk kültüründe iş ahlakı ve sosyal sorumluluk. Siyasette ve Yönetimde Etik Sempozyumu bildiriler kitabı içinde (s. 541-554). Adapazarı: Sakarya Üniversitesi.

Ünsür, A. (2017). Ahilik sisteminde ahlak temelli çalışma ilişkileri ve günümüz bakış açısından değerlendirilmesi. Yalova Sosyal Bilimler Dergisi, 8(13), 90-98.

Ünsür, A. (2018). Işs'te insan ve ahlak. İstanbul: Aktif Matbaa ve Reklam.

Ünsür, A. (2020). İnsan kaynakları yönetimine ahlaki perspektif: İKY süreçlerinin ahlaki değerler açısından değerlendirilmesi. İş Ahlakı Dergisi, 12(2), 95-154.

Vurgun L. \& Öztop S. (2011). Yönetim ve örgüt kültüründe değerlerin önemi. Süleyman Demirel Üniversitesi İ̈BF Dergisi, 16(3), 217-230.

Wiener, Y. (1988). Forms of values systems: A focus on organizational effectiveness and cultural change and maintenance. Academy of Management Review. 13, 534-545.

Wittek, P. (1971). Osmanlı imparatorluğunun kuruluşu (G. Yalter Çev.). İstanbul: Türkiye Yayınevi.

Yahya b. Halil (ty). Fütüvvetname. Millet Kütüphanesi Yazma Eserler (Ulum-u Şer'iyye).

Yaran, C. S. (2015). Íslam'a göre ahlaki davranış ve kıstaslarl; İslam ahlakı. Ankara: Diyanet İşleri Başkanlığı.

Yeşil, R. \& Kart, M. (2018). Değer eğitimi modeli olarak ahilik. MANAS Sosyal Araştırmalar Dergisi, 7(3), 161-177.

Zaim, H. (2013). İş hayatında erdemli insanın yetkinlikleri ile performans arasındaki ilişki. Istanbul Ticaret Üniversitesi Sosyal Bilimleri Dergisi, 12(23), 181-196.

Zaim, S. (1992). Íslam-insan ekonomi. İstanbul: Yeni Asya Yayınları.

Zaim, S. (1994). Ekonomik hayatta Müslüman insanın tutum ve davranışlarl; $\dot{I}_{S ̧}$ hayatında İslam insanı. İstanbul: MÜSİAD Yayınları. 


\title{
Management and Education in Akhism System
}

\author{
Ahmet ÜNSÜR, Corresponding Author, PhD. (Ret. Lecturer) \\ Sakarya University, Faculty of Economics and Administrative Sciences, Turkey. \\ aunsur37@gmail.com \\ https://orcid.org/0000-0001-6560-4620
}

Article Type: Review Article

https://doi.org/10.34234/ded.667411

Received Date: 30.12.2019

Accepted Date: 12.05 .2020

Published Date: 25.06.2020

\section{Introduction}

It is observed that with the influence of capitalism, which ignores moral values, and merely celebrates and emphasizes economic values, moral problems increasingly continue to be manifested in almost all parts of business and social life (Bell, 1978, p. 206-222; Tuna and Yalçıntaş, 1997, p. 157-158; Zaim, 1992, p. 19). Approaches and practices of social responsibility (Bowen, 1953), which have been brought to the agenda since the 1950s, are also seen to be short of providing the expected solution (Hamel \& Breen, 2007, p. 22; Mondy, 2017, p.26; Porter and Kramer, 2005, p. 37). On the other hand, Islam with its universal quality (Surat al-Imran, 3:19) has laid approaches that emphasize the moral values (for example, the ahilik system) are seen to be effective in the solution of the aforementioned problems (Es-Sadr, 1980, p.300; Hamitoğulları, 1987, pp. 30-31; Mannan, 1989, p. 52; Zaim, 1994, p. 102). In this study, the Akhism system, which has been operating for hundreds of years, will be examined with its values and educational practices. 


\section{Values, Management and Education}

\section{What is Value?}

Derived from the Latin word valere (Bilgin, 1995, p. 83), the concept of value (MacMillan Dictionary, 1988; TDK, Actual Turkish Dictionary) creates 'standards and beliefs that determine and guide the preferences and behaviors of individuals or groups' (Covey, 2008, p. 366-367; Güngör, 1993, p. 27; Herriot, 1976, p. 18; Kilby, 1993, p. 33; Kluckhohn, 1951, p. 395; Lennick and Kiel, 2005, p. 44; Poyraz, 2007, p. 83; Rokeach, 1973, p. 5; Suparka and Johnson, acted in 1975. Kaymakcan and Meydan). Historical, cultural, social, economic, etc. factors have a significant impact on the formation of values (Güney, 2015, p. 122; Lennick \& Kiel, 2005, p. 44; McCrae, 2004, p. 4; Özensel, 2003, 229; Schwartz, 1994, p. 3; Triandis and Suh , 2002, p. 133). Values are the cultural codes that hold the individuals together and separate the groups/societies from others (Durkheim, 1986, p. 22-24; Güngör, 1993, p. 27-28). In that respect, to consider the subject within education is very important for the future of organizations/societies (Ülken, 2013, p. 298-300).

Moral values are built on beliefs, they guide attitudes and behaviors, they define things as good or bad (Arslan and Berkman, 2009, p. 32; Baltaş, 2009, p. 97-106; Boyatzis, 2005, p. Xxiv; Dose and Klimoski, 1999, p. 85; Topçu, 2006, p. 35; Türkeri, 2011, p. 402; Ülgener, 2016, pp. 8-10). According to Islam, values should be determined by a superhuman authority (Surah Yusuf, 12:40). Otherwise, its absolute and general acceptance becomes controversial (Çağrıc1, 2013, p. 129).

\section{Management and Values}

Values are the most important tools in management, they have a guiding and motivating effect when setting goals and creating actions (Delgrosso, 2004, p. 26; Doğan, Aşkun and Yozgat 2007, p. 23; Ennulo and Türnpuu, 2001, p. 344; Eren, 2010 , p. 220; Şişman, 2002, p. 94; Wiener, 1988). Organizational values set the baisi of the criteria in qualifying, evaluating and judging employees' behavior (Sabuncuoğlu \& Tuz, 2001, p. 43; Şişman, 2002, p. 95).

It is known that there is a strong relationship between organizational values-based management and employees' commitment to organization, job sat- 
isfaction and organizational success level (Argüden, 2004, p. 19; Demir, 2002, p. 3-7; Hazlitt, 2002, p. 15; Ştefanescu and Doval, 2010, p. 36-38; Vurgun and Öztop, 2011, p. 226). Researches show that there is a strong relationship between business end results and values (Baltaş, 2009, p. 100; Barutçugil, 2004, p. 223-224; Zaim, 2013, p. 193-194).

\section{Values and Education}

Education; is a set of activities that aim to provide the person with knowledge and skills, regulating his/her emotions and behaviors and creating moral character/behavior (Acluni, C. 1, 391; Andrews, 2005, p. 73; Aydın, 2003, p. 139; Çamdibi, 1983, p. 13 ; Eren, 2010, p. 84; Kaymakcan and Meydan, 2014, p. 21-41; Kerschenstainer, 1977, p. 8; Noe, 1999, p. 4; Sabuncuoğlu, 2011, p. 124; Özçelik, 2013, p. 165; Ulken, 2001, p. 22-25 and 2013, p. 182; Yaran, 2015, p. 73-80). Education of values plays an important role in guiding the power obtained through education (Arslan \& Berkman, 2009, p. 36; Berkowitz, 2011, p. 153; Gregoire, 1971, p. 17; Kaymakcan \& Meydan, 2014, p. 137; Kelly, 1987, p. 22; Kuçuradi, 2003a, p. 16; Kuçuradi, 2003b, p. 9; Pazarl1, 1972, p. 13). Countries' education system is what determines the social and cultural values (Cramer and Browne, 1977, p. 23; Pazarl1, 1972, p. 43-45; Ünsür, 2018, p. 11).

With values education, it is possible to raise honest and moral individuals with strong personality. (Bertrand, 2001, p. 2). Therefore, appropriate environments should be created and necessary resources should be provided (Çağlayan, 2005, pp. 92-93; Hökelekli and Gündüz, 2007, p. 389).

\section{Akhism System, Its Values and Education}

\section{What is Akhism?}

Akhism; It is the name of a union of tradesmen, whose source is Islam, and which is based the senses of brotherhood (Surat Hujurat, 49:10), whose aim is raising virtuous and productive individuals, with solidarity-based system that integrates morality and art.(Ahmed Rif'at, 1881, C. 1, p. 106; Bayram, 1995, p. 29; Çağatay, 1997, p. 44; Ekinci, 2008, p. 19; TESK, 1973, p. 27-33; Evliya Çelebi, C. 1 p. 504; Faroqhi, 2011, p. 84; Hamitoğulları, 1986, p. 13; Kazıcı, 1988, p. 540; January, 1996, p. 261-263; Pekolcay, 1986, p. 77; Soykut, 1980, p. 17; Ülgener, 2006, p. 94-95; Wittek, 1971, p. 37). 
Established by Ahi Evran (1171-1261), due to the prestige and appreciation it garnered, Akhism has been influential in the strengthening and stabilizing the business life and social structure alike (Çağatay, 1997, p. 50; Ülgener, 2006, p. 67). Being based on values and quality in its management, it is possible to qualify its type of management in Akhism as a management with values, the same is true for its type of education therefore it is possible to qualify it as education with values. (Araz et al., 1994, p. 132; Faroqhi, 2011, 69). It is known to exemplify internationally with these aspects (Akao, 1999, p. 20; Greinert, 1996, p. 6-12; Gülerman and Taştekil, 1993, ss. 5-9; Klause, 1996, p. 13-17; Şimşek ,2000, p. 131).

Having a legitimate job and profession in Akhism and making a profit for labor is compulsory (Ekinci, 2008, p. 23; Lewis, 1973, p. 146; Surah Necm, 53:39). In professional relations, besides professional knowledge, justice and benevolence (Surat an-Nahl, 16:90) were regarded as values to be observed, and the world-hereafter balance (Ramuz-ul Ehadis, C. 1, 282) adopted as its philosophy (Çağrıc1, 2013, p. 277-280).

Akhism is also a system that stands out with the Sufi approach it has (Kazic1, 1988, p. 541; Köprülü, 1981, p. 213; Kütükoğlu, 1986, p. 55; Uludağ, 1996, p. 261). Bravery, generosity and hospitality formed the basis of the system (Çağatay, 1994, p. 105; Ülgener, 2006, p. 64). Basic values and principles of Akhism are put in a constitution named "fütüvvetname" that contains principles of moral and commercial rules (Çağatay, 1997, p. 1). In "fütüvvetname" the principles of Akhism with the moral and commercial rules have been defined (Kazıc1, 1988, p. 541; Kütükoğlu, 1986, p. 60). Since the 13th century it has been observed that alongside high-level statesmen, merchants and scientists have joined the Akhism organization, which has left its mark on political, social, cultural and economic life and therefore has become an organization with high status and reputation (Kazıc1, 1988, p. 540; Tabakoğlu, 2008, p.43).

\section{Values of Akhism System}

The principles and values of the Akhism system are defined in "fütüvvetname". It is observed that the principles and values included in the "fütüvvetname" contain Islamic elements. Moral competence was put as a prerequisite requirement for recruitment (Muallim Cevdet, 1919, p. 155-156; Çağatay, 1997, p. 163).

It is possible to summarize the basic moral values of Akhism included in "fütüvvetname" as follows; 
- Having a legitimate job and profession in accordance with their competencies,

- To learn and preserve the subtleties of the craft under the supervision of a master,

- Not inclined to seek more than one job,

- Perseverance in your profession and strive for progress,

- To be honest in all matters,

- Not to be greedy and to be content,

- Being submissive and loyal,

- To be knowledgeable, to love scholars,

- Being proud of the job and profession, having collective consciousness,

- Producing a product with a quality that will not harm the reputation of the profession,

- Not to hurt anyone,

- Being hospitable, generous, humble and moral ((Kinalızade, C. 1, p. 157; Sülemi, 1977, p. 24-94; Ülgener, 2006, p. 57-120).

\section{Values Education in Akhism System}

It is fair to savy that Akhism is a values education institution, since it prioritizes people and believes that they can be elevated by values (Bayram, 1995, p. 38; Bukhari, Edeb, 38, 39). It aims to raise a good businesspersons and citizens who are devout, moral, competent in their profession, constantly improve themselves, have a sense of responsibility, and who add value to the environment they are in (Kazıc1, 2006, p. 70; Ünsür, 1988, p. 547). It is observed that today's education systems set similar goals (Güvenç et al., 1998, p. 17-60; TC. Official Gazette, 24 June 1973, Number: 14574).

As a non-formal education institution (Akyuz, 1985, p. 47), education in Akhism, is planned and managed with a Sufi approach (Bayram, 1995, p. 48-49; Ünsür, 2018, p. 417-418). Apart from schools and madrasas, workplaces / bazaars, lodges, mosques and Yaran houses were also used as educational environments (Çağatay, 1997, p. 213-214; Ekinci, 2008, p. 78-147; Kazıc1, 2006, p. 69-71; Fingerless, 1971, p. 9; Tabakoglu, 1986, p. 417-418 and 2008, p. 250). The lodges, which are managed with foundational understanding, are multifunctional structures among which is hosting the guests and these structures have been built in accordance with the mission of Akhism (Çağatay, 1997, p. 50; Güllülü, 1977, p. 64; Noe, 1999, p. 135; Önge, 1988, p. 531 ). It is known that madrasahs and schools became widespread in this period and wealthy peo- 
ple made important investments in this field (Bayram, 1981, p. 50 and 1995, p. 41; Sevinç, 1992, p. 130-139).

In addition to reading and writing education in Akhi lodges, lessons in Quran, hadith, biography of the Prophet, catechize, fütüvvetname, etiquette, citizenship, military service, history, sufism, literature, Turkish and Arabic grammar, fine writing and music is being taught. (Çağatay, 1997, p. 244-246; Ekinci, 2008, p. 61-78; Muallim Cevdet, 1919, p. 77-78; TESK, 1973, p. 29). Also a number of methods used in today's conversational training had been used then (Kandemir, 1979, pp. 373-400; Kaya, 2013, pp. 47-49; Ryan, 1991, pp. 99-105; Sülemi, 1977, pp. 60-61; Yeşil ve Kart, 2018, p.166) Those who teach at the lodges were called teacher Akhi, Pir or Emir. The city's Kadı (Judge) and female teachers also used to teach there(Köprülü, 1981, p. 402). Scientists, Kadis, teachers and high-level state officials from all branches attend the evening meetings in the Akhi lodges (TESK, 1973, p. 31). In villages, similar activities were organized in the Yaran rooms (Çağatay, 1994, p. 112-148).

Promotion ceremonies were also used as educational activities in Akhism. In these ceremonies, the importance of complying with values and professional ethics is emphasized and some advises are given (Çağatay, 1997, p. 137-157; Ergin, 1922, p. 692-711; Sevinç, 1992, p. 103).

In addition to the informative function of the education in Akhism, the entertaining and relaxing aspect has not been neglected. Texts about Muhammad's (PBU) life and devotion are read in Helva Gatherings (Faroqhi, 2011, p. 70).

In Akhism events were organized on certain days of the year which is similar to today's outdoor activities. Banquet and three days of gathering are among the activities (TESK, 1973, pp. 61-64). On the other hand, it is known that agricultural workers of Akhis are gathered at the end of threshing season in an appropriate place where they chat, have fun and mingle.

\section{The Collapse of the Akhism System}

Towards the end of the 16th century, the dissolution of ahi units began to show itself (Ekinci, 1989, p.55-56; TESK, p. 49-125). although external factors such as change in trade routes and economic fields and the interventionist policies of the state in this field have been shown as the main reason behind the dissolution, it should not be overlooked that any structure in which internal factors maintain the dynamism cannot be destroyed only by external factors. It is noteworthy that 
through this process, values have been neglected, the efficiency of education has decreased and solidarity based on social fraternity has started to be replaced by economic cooperation based on economic interests (Türkdoğan, 1981, p. 671; Ülgener, 2006, p. 147-148).

Despite the corruption that has started for various reasons in the Akhism system it is difficult to claim that this structure that based on moral values has been completely disappeared. As a matter of fact, the impressions of the 18th and 19th century travelers to the Ottoman geography reflected this fact. (D'ohsson, ty, p. 129). Today, it is possible to find traces of Akhism in economic and social fields, especially in Anatolia.

\section{Conclusion and Suggestions}

It is possible to describe the model of organization in Akhism, as educational and managemental understanding based on moral values, which can be expressed as a learning organization in today's terms (Mondy, 2017, p. 166; Noe, 1999, p. 142-143). The main ingredient of learning organizations is holding on moral values so that the possible risks of encountering problems are reduced significantly (DeCenzo et al., 2017, p. 20). This feature has served as a protective shield for many centuries.

When Akism is evaluated in terms of today's education system, there are many examples that can be followed. The first of these is to integrate general and vocational education programs with values, and to make the planning and implementation appropriate for this. Values education should cover the whole process starting from pre-school, all educators should be competent in this regard, not only educational institutions but also families, non-governmental organizations and all segments of the society should be transformed into a part of the process and their participation should be ensured. Only in this way it will be possible to become an individual, organization or society that learn, share, and act in solidarity as duty. It should not be forgotten that overcoming today's problems arising from ignoring moral values may be possible by associating values with every stage of life. 